\title{
Specialized Pro-Resolving Lipid Mediators: The Future of Chronic Pain Therapy?
}

\author{
Mervin Chávez-Castillo ${ }^{1}$, Ángel Ortega ${ }^{1}\left(\mathbb{D}\right.$, Lorena Cudris-Torres ${ }^{2} \mathbb{D}$, Pablo Duran ${ }^{1}\left(\mathbb{D}\right.$, Milagros Rojas $^{1}(\mathbb{D}$,

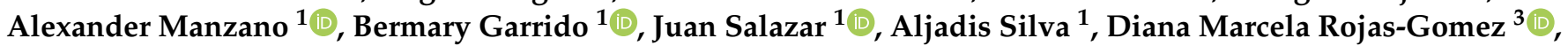 \\ Juan B. De Sanctis ${ }^{4}$ and Valmore Bermúdez ${ }^{5, *(\mathbb{D})}$
}

1 Endocrine and Metabolic Diseases Research Center, School of Medicine, University of Zulia, Maracaibo 4004, Venezuela; mervinch12@gmail.com (M.C.-C.); angelort94@gmail.com (Á.O.); pabloduran1998@gmail.com (P.D.); migarocafi@gmail.com (M.R.); amanzano_8@hotmail.com (A.M.); bermarygarrido@gmail.com (B.G.); juanjsv18@hotmail.com (J.S.); aljadisenrique@gmail.com (A.S.)

2 Programa de Psicología, Fundación Universitaria del Área Andina sede Valledupar, Valledupar 200001, Colombia; lcudris@areandina.edu.co

3 Escuela de Nutrición y Dietética, Facultad de Medicina, Universidad Andres Bello, Santiago 8370035, Chile; diana.rojas@unab.cl

4 Institute of Molecular and Translational Medicine, Palacký University Olomouc, 77900 Olomouc, Czech Republic; sanctisj@gmail.com

5 Facultad de Ciencias de la Salud, Universidad Simón Bolívar, Barranquilla 080002, Colombia

* Correspondence: v.bermudez@unisimonbolivar.edu.co

check for updates

Citation: Chávez-Castillo, M.; Ortega, Á.; Cudris-Torres, L.; Duran, P.; Rojas, M.; Manzano, A.; Garrido, B.; Salazar, J.; Silva, A.; Rojas-Gomez, D.M.; et al. Specialized Pro-Resolving Lipid Mediators: The Future of Chronic Pain Therapy?. Int. J. Mol. Sci. 2021, 22, 10370. https:// doi.org/10.3390/ijms221910370

Academic Editor: Alain Couvineau

Received: 31 August 2021

Accepted: 23 September 2021

Published: 26 September 2021

Publisher's Note: MDPI stays neutral with regard to jurisdictional claims in published maps and institutional affiliations.

Copyright: (c) 2021 by the authors. Licensee MDPI, Basel, Switzerland. This article is an open access article distributed under the terms and conditions of the Creative Commons Attribution (CC BY) license (https:// creativecommons.org/licenses/by/ $4.0 /)$.

\begin{abstract}
Chronic pain (CP) is a severe clinical entity with devastating physical and emotional consequences for patients, which can occur in a myriad of diseases. Often, conventional treatment approaches appear to be insufficient for its management. Moreover, considering the adverse effects of traditional analgesic treatments, specialized pro-resolving lipid mediators (SPMs) have emerged as a promising alternative for $\mathrm{CP}$. These include various bioactive molecules such as resolvins, maresins, and protectins, derived from $\omega-3$ polyunsaturated fatty acids (PUFAs); and lipoxins, produced from $\omega-6$ PUFAs. Indeed, SPMs have been demonstrated to play a central role in the regulation and resolution of the inflammation associated with CP. Furthermore, these molecules can modulate neuroinflammation and thus inhibit central and peripheral sensitizations, as well as long-term potentiation, via immunomodulation and regulation of nociceptor activity and neuronal pathways. In this context, preclinical and clinical studies have evidenced that the use of SPMs is beneficial in $\mathrm{CP}$-related disorders, including rheumatic diseases, migraine, neuropathies, and others. This review integrates current preclinical and clinical knowledge on the role of SPMs as a potential therapeutic tool for the management of patients with CP.
\end{abstract}

Keywords: chronic pain; specialized pro-resolving lipid mediators; inflammation; long-term potentiation; central nervous system sensitization; polyunsaturated fatty acids; eicosanoids; nociception; omega 3 fatty acids; pain management

\section{Introduction}

Chronic pain (CP) is one of the most frequent and difficult-to-manage clinical entities in medical practice [1]. Multiple disorders featuring CP are the leading causes of disability worldwide, corresponding to a significant public health issues [2-4]; as well as marked reductions in quality of life related to restrictions of mobility and daily activities, anxiety, and depression [5,6]. Current pharmacological options for the treatment of CP are imperfect, including significant efficacy and tolerability issues [7]. In particular, opioid abuse has been linked to increasingly larger mortality rates in recent years, representing a large-scale epidemic $[7,8]$.

These problems have invigorated neuropharmacological research on CP [9], centering on neuroinflammation as a therapeutic target [10]. Inflammation as a pathophysiologic 
component of pain has long been recognized in neural phenomena such as peripheral sensitization (PS), central sensitization (CS), and long-term spinal potentiation (LTP) [11]. Recent preclinical and clinical studies have described anti-nociceptive effects for specialized pro-resolving lipid mediators (SPMs), which derive from polyunsaturated fatty acids (PUFA) [12-15]. These molecules are important regulators of the balance between proinflammatory and anti-inflammatory substances, in addition, they might regulate the excessive sensitization of nociceptors after inhibiting specialized channels and thus achieving the suppression of pain [13]. In this way, SPMs would function as a bridge between the immune and nervous systems, and could be the future of $\mathrm{CP}$ therapy. The objective of this review is to describe the molecular pharmacological mechanisms through which SPMs act in CP, as well as summarize current preclinical and clinical evidence on SPMs as analgesic agents, serving as a novel approach to $\mathrm{CP}$ management.

\section{Materials and Methods}

This is a narrative review in which an extensive literature search was performed on Scopus, EMBASE, PubMed, ISI Web of Science, and Google Scholar databases, from inception to August 2021. The terms "Chronic pain", "Neuroinflammation", "specialized pro-resolving lipid mediators and chronic pain", and "Chronic pain and nociception" were among the ones used throughout the search.

\section{Results}

\subsection{Specialized Pro-Resolving Lipids Mediators in Pain: The Molecular Basis}

SPMs are synthesized in an active metabolic process in the latter stages of inflammation, acting as a regulatory mechanism, decreasing pain caused after sensitization of nociceptors, and limiting local tissue damage caused by the inflammatory response [11]. A variety of PUFA are well-recognized substrates for SPM synthesis, including both $\omega-6$ fatty acids such as arachidonic acid (AA), and $\omega-3$ fatty acids such as eicosapentaenoic (EPA), docosahexaenoic (DHA), and docosapentaenoic acids (DPA) [16,17]. Thus, after activation of intracellular phospholipases, these molecules can be used as the initial substrate in the SPMs synthesis pathways, yielding products in two families: Lipoxins (LX), derived from $\mathrm{AA}$, and protectins $(\mathrm{PD})$, maresins $(\mathrm{MaR})$, and resolvins (Rv), derived from the $\omega-3$ fatty acids [18] (Figure 1). The latter may be further categorized into two groups: E-series (RvE) and D-series (RvD) resolvins. RvE synthesis involves cyclooxygenase-2 activity, as well as processing by lipoxygenases such as 5-lipoxygenase (5-LOX), which forms RvE1.

Alternatively, RvD may be produced from DHA via 5-LOX and 15-lipooxygenase (15-LOX) to form 17S-hydroperoxy-DHA, which can finally be converted to RvD1, RvD2, RvD3, and RvD4. Interestingly, acetylsalicylic acid (AAS) appears to induce the synthesis of RvD and LX by acetylating COX-2 and thereby changing its enzymatic properties [19,20]. DHA may also be a precursor of PD and MaR [21], which are abundant in murine and human neurons and macrophages, respectively [22,23]. Despite the close relationship between PUFAs, SPMs and inflammatory pathology improvements, the mechanism in which COX-2 acetylation is involved continues to be discussed nowadays.

Furthermore, the synthesis of SPMs is key for promoting an anti-inflammatory and pro-resolution state, and by extension, relieving peripheral inflammatory pain [17]. This change from a pro-inflammatory to an anti-inflammatory state appears to hinge on a phenotypic modification in 15-LOX functionality induced by a PGE2 peak, which propels a shift from the production of leukotriene B4 (LTB4) to LX, leading to Rv, PD, and MaR synthesis $[24,25]$. This process is driven by increased translation of key enzymes for ARNm codification $[26,27]$. 


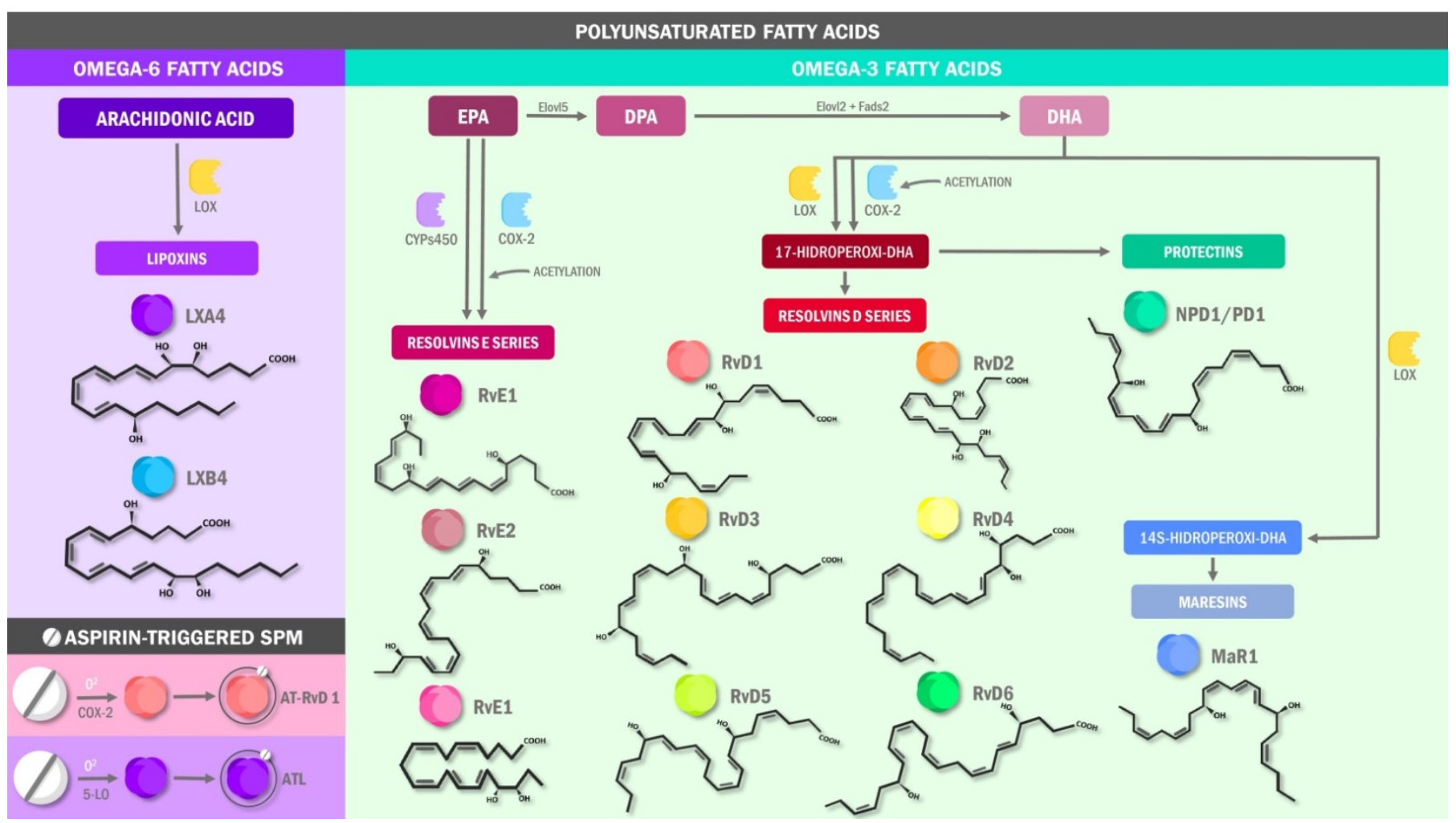

Figure 1. Metabolism of specialized pro-resolving lipid mediators. EPA: eicosapentaenoic acid; DPA: docosapentaenoic acid; DHA: docosahexaenoic acid; RvE1: resolvins E1; RvE2: resolvins E2; RvE3: resolvins E3; RvD1: resolvins D1; RvD2: resolvins D2; RvD3: resolvins D3; RvD4: resolvins D4; RvD5: resolvins D5; RvD6: resolvins D6; NPD1: neuroprotectins 1; MaR1: maresins 1; LXA4: lipoxins A4; AT-RvD: aspirin-triggered resolvin D1; ATL: aspirin-triggered lipoxins; LOX: lipoxygenases; COX-2: cyclooxygenase 2; CYP: cytochromes P450 enzymes.

In turn, SPMs activate a variety of receptors in several immune cells, for example, the $\mathrm{N}$-formyl peptide receptor 2 (ALX/FPR2), widely recognized in neutrophils, monocytes, T cells, synovial fibroblasts, and glial cells; whose main ligands are LXA4 and ATL [28]. Moreover, LX have been observed to antagonize pro-inflammatory mediators such as IL- 6 and IL-8 in various cells in the respiratory tract and inhibit TNF- $\alpha$ release in human T cells [29]. In polymorphonuclear cells (PMN), LX also activate ALX/FPR2, decrease leukocyte infiltration and inhibit transmigration, adhesion, degranulation, and chemotaxis of neutrophils, as well as the generation of superoxide. Rapid phosphorylation of Lymphocyte-specific protein 1 (LSP1) and polyisoprenyl phosphates is a paramount step in this process [30]. Likewise, LXA4 competes with other ALX/FPR2 ligands such as LTB4, PGE2, and N-formyl-Met-Leu-Phe peptide (fMLP), reducing their activity in PMN [30-35]. In addition, by disrupting chemotaxis, SPMs may also indirectly prevent the formation of neutrophil extracellular traps, thus attenuating further recruitment and favoring resolution of inflammation [36].

On the other hand, LX are the main products obtained from AA in this context, via 5-LOX and 15-LOX oxygenation. This yields LXA4 and LXB4, which have been isolated from endothelial cells, leukocytes, and human platelets [37]. Notably, ASA appears to promote the production of 15R-hydroperoxy-eicosatetraenoic acid, a substrate for 5-LOX to form 15-epi-LXA4, an LX epimer. These aspirin-triggered lipoxins (ATL) may have unique and beneficial biological properties in comparison with the effects of other related agents, such as non-steroidal anti-inflammatory drugs (NSAID). Indeed, ATL may correlate to a key role for ASA specifically in the clinical management of inflammatory and CP-related disorders [26,38].

The activation of ALX/FPR2 also appears to induce changes in the phosphorylation of cytoskeleton proteins, arresting the cell cycle and preventing phosphorylation in pro- 
inflammatory pathways, like the activation of nuclear factor kappa B (NF-kB) [30,39]. Moreover, LXA4 can also antagonize CysLT1 receptors in PMN, endothelial and mesangial cells [40]; and inhibit proliferation induced by leukotriene D4 by modulating plateletderived growth factor receptor (PDGF) transactivation, and therefore, phosphoinositoside 3-kinase (PI3K) activation and the mitogenic response [31]. In neurons, LXA4 signaling can also be potentiated by sphingosine-1-phosphate, which can acetylate neuronal COX-2 to drive a skew towards the production of the powerfully pro-resolutive 15-epi-LXA4, similarly to the events seen in the synthesis of ATL [41]. Lastly, both LXA4 and LXB4 may also inhibit the chemotaxis of neutrophils induced by LTB4, as well as eosinophil degranulation by PDGF [31].

In other cell types, such as monocytes, LX promote the resolution of inflammation, as they are capable of mediating chemotaxis and adhesion without the release of reactive oxygen species (ROS) and degranulation [42]. Furthermore, in macrophages, LXA4 stimulates phagocytosis of apoptotic PMN [12]. This process occurs via activation of small GTPases, with the subsequent redistribution of cytoskeletal proteins for the assembly of cytoplasmic extensions and pseudopods [43]. Meanwhile, in neutrophils, similar changes are mediated by inhibition of protein kinase C-BII (PKCBII). This enzyme promotes inflammation by triggering the conversion of polysoprenyl diphosphate phosphatase 1 into presqualene diphosphate and then presqualene monophosphate, a positive stimulus for several functional cell responses in inflammation [44]. On the other hand, transforming growth factor $\beta$ (TGF- $\beta$ ) is synthesized during phagocytosis, which actively suppresses the release of pro-inflammatory cytokines [45], and promotes SPMs biosynthesis, further favoring resolution [46]. Finally, activation of ALX/FPR2 can inhibit IL-10 production by B cells and TNF- $\alpha$ in T cells, highlighting the anti-inflammatory role of SPMs in the adaptive immune response, as seen in chronic inflammation $[47,48]$.

Other SPMs with notable mechanisms of action include RvD and RvE. Particularly, RvD1 shares the affinity for the ALX/FPR2 receptors with LXA4; and also binds to other GPCR, such as DRV1/GPR3. These receptors are found in PMN, monocytes, macrophages, and endothelial cells. Their activation appears to involve upregulation of specific microRNA such as miR-208 and IL-10 while downregulating miR-219, which modulates 5-LOX and reduces LTB4 levels [21,49]. RvD1 can also reduce actin polymerization and CDb11 activity [50], powerfully promoting leukocyte adhesion, migration, and phagocytosis [51]. Others, like RvD3 and RvD5, also act on these receptors [12]. Another recently discovered receptor, DRV2/GPR18 - found in bone marrow, monocytes, and macrophages-is also activated by RvD2, in association with increased phagocytosis via modulation of the protein kinase A (PKA) and STAT3 pathways [52,53]. RvD may also inhibit the synthesis of INF-y and TNF- $\alpha$ in Th1 and Th17 cells, resulting in increased production of Treg cells, lower IL-6 levels, and increased production of IgM and IgE by B cells [54]. RvD1 can inhibit the class change of $\operatorname{IgG}$ to $\operatorname{IgE}$ by stabilizing regulatory protein BCL-6. These events reflect the role of SPMs in allergic processes [48,55].

Interestingly, neuropathic pain in microglia activates by phosphorylation mitogenactivated protein kinase (MAPK), increasing prostaglandin E2 (PGE2), which mediates microglial activation and subsequent pain enhancement, as counter-regulators RvD1 and LXA4 in microglia can inhibit TNF release, an important factor in pain mediation [56]. In addition, RvD1 has functions as a promoter of conjunctival cell health using a different mechanism than the one mentioned before, which is the stimulation of mucin secretion by goblet cells. This is mediated by intracellular calcium increase [57]. In the case of $\mathrm{RvD2}$, it has a similar role but it also increases nitric oxide and prostacyclin production in endothelial cells as well as microbial killing promotion. This results in controlled PMN adhesion, thus acting as an anti-inflammatory substance [58].

Among RvE, RvE1, and RvE2 can bind to ERV1/Chem23 receptors, abundantly expressed in monocytes, and more sparsely on neutrophils, M2 macrophages, and dendritic cells. RvE1 can compete with chemerin, a pro-inflammatory ligand of this receptor, resulting in inhibition of signaling by NF-kB, MAPK/ERK1-2, and PI3K/AKT [59,60], which 
are essential for inflammation and phagocytosis [12,61]. RvE1 is also a partial agonist of the LTB4 receptor, blocking the calcium-mediated intracellular response induced by this leukotriene in leukocytes, and inhibiting chemotaxis [62,63]. Furthermore, RvE1 is one of the few SPMs that can inhibit cytokine production in Th2 cells [54].

On the other hand, MaR activity is prominent in macrophages, where they may be synthesized from DHA [64]. 13S, 14S-epoxide maresin induces the differentiation of pro-inflammatory M1 macrophages to M2 macrophages, which poses anti-inflammatory and pro-resolving properties, releasing PDGF, IL-10, and TGF- $\beta$ [65]. MaR1 increases phagocytosis and activates PKC isoforms, which limit neutrophil infiltration, decrease IL-6, TNF- $\alpha$, and chemokine production. It also prevents the activation of NF- $\mathrm{KB}$ by inhibiting IkB kinase (IKK), not allowing the dissociation of the inhibitor of NF- $\mathrm{KB}(\mathrm{I} \kappa \mathrm{B} \alpha)$ from NF-kB itself [66-69]. Even though it is not part of the SPMs family, flavonoids-derivate pharmaceutics, such as Flavocoxid, have been studied as pro-resolving therapeutics that have a similar mechanism to MaR, specifically as a possible inhibitor of NF-kB. It also acts as a dual inhibitor of COX-2 and 5-LOX. Furthermore, it has been associated with increased levels of LXA4 production [70]. Finally, other SPMs may also modulate immune cell functionality and cytokine synthesis: PD appears to inhibit $\mathrm{T}$ cell migration and promote their apoptosis in vivo, in association with lower TNF- $\alpha$ levels [71]. It also reduces signaling by NF-kB, expression of COX-2, and infiltration by PMN. PD1 is also a ligand for GPR37, promoting phagocytosis of apoptotic cells in inflammation. However, the underlying mechanisms remain unclear [72-74].

\subsection{Specialized Pro-Resolving Lipids Mediators in the Neurobiology of Pain: Anti-Inflammatory and Analgesic Mechanisms}

A large part of the pharmacological interest in SPMs focuses on their capacity for modulation of neuroinflammation, as pain results from the interplay between immune and nervous cells. Historically, the resolution of the inflammatory response was construed as a passive process depending on the spontaneous wane of pro-inflammatory factors. However, at present, active modulation by various immune cells is recognized as a paramount factor in this process [12,75]. SPMs may be the key mediators in this context, as explained before, relieving peripheral inflammatory pain [17].

Peripheral inflammatory pain is a consequence of the sensitization of peripheral nociceptors by various signals, such as the recruitment of macrophages and neutrophils, which secrete mediators that promote the sensitization of such nociceptors [76]. These include pro-inflammatory cytokines such as TNF- $\alpha$, IL-1 $\beta$, IL-6, and IL-17, nerve growth factor (NGF), serotonin, histamine, and prostaglandin E2 (PGE2), among others [77]. Furthermore, local release of nitric oxide (NO) by inflammatory stimuli is been associated with peripheral nociception. Several studies have suggested PGE2 increased production of PGE2 in the presence of NO, due to the ability of NO to activate COX-1 and up-regulate COX-2, which leads to peripheral release of PGE2 and PGI2 [78]. Sensory neurons express receptors for a number of these mediators, including IL-1 $\beta R$, TNF- $\alpha$ R, IL-6R, and IL-17RA, NGF receptors (TrkA), and G protein-coupled receptors (GPCR) for serotonin, histamine, and PGE2 [77,79-81]. These are expressed in both type $C$ and A $\delta$ nociceptive fibers [82], and their activation enhances membrane excitability, leading to subsequent stimulation due to the hyperactivation of key transduction molecules, such as transient receptor potential vanilloid subtype 1 (TRPV1) and ankyrin subtype 1 (TRPA1) ion channels, and conduction molecules such as tetrodotoxin-insensitive voltage-gated sodium channels Nav1.7, 1.8, and 1.9. This process results in PS, with decreased activation thresholds in primary nociceptors [83]; and in turn, it augments the release of excitatory neurotransmitters at terminal synapses within the dorsal horn (DH) of the spinal cord, a key site for sensory signal modulation. This hyperactivation further sensitizes second-order sensory neurons, triggering neuronal plasticity and CS, a circumscribed state of hyperexcitability in the central nervous system with enhanced processing of nociceptive signals (Figure 2) [50]. 


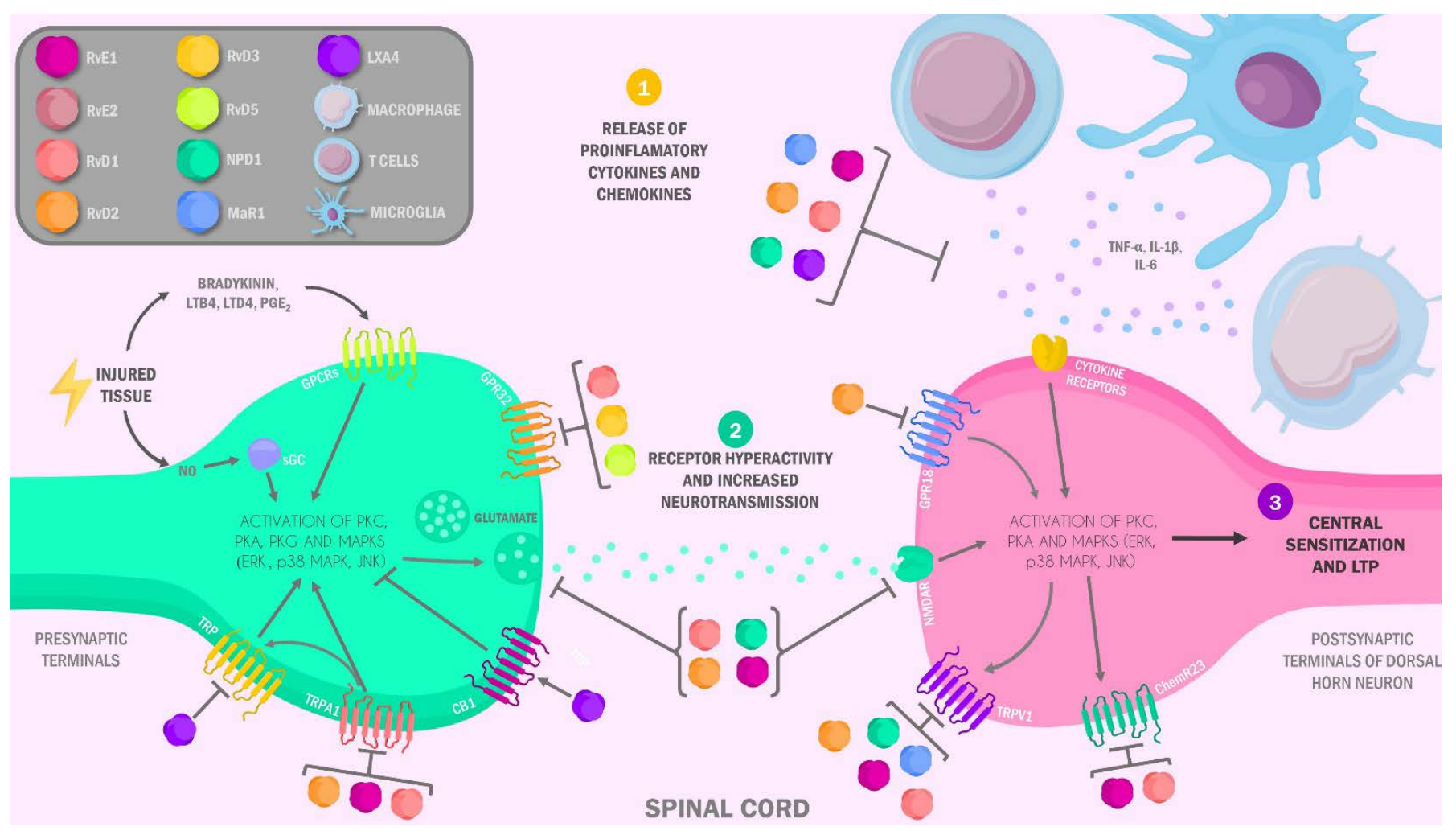

Figure 2. Role of specialized pro-resolving lipid mediators in central sensitization and long-term spinal potentiation in pain. Inflammation caused by local or peripheral injury impacts the nervous system through pro-inflammatory mediators secreted by immune and specialized cells, with the subsequent upregulation and hyperactivity of nociceptors and other receptors related to pain perception, leading to uncontrolled synaptic activity and development of central sensitization and long-term spinal potentiation. RvE1: resolvins E1; RvE2: resolvins E2; RvD1: resolvins D1; RvD2: resolvins D2; RvD3: resolvins D3; RvD5: resolvins D5; NPD1: neuroprotectins 1; MaR1: maresins 1; LXA4: lipoxins A4; LTB4: leukotriene B4; LTD4: leukotriene D4; PGE2: protaglandines E2; GPCRs: G protein-coupled receptors; TRP: transient receptor potential; TRPV1: transient receptor potential vanilloid subtype 1; TRPA1: transient receptor potential cation channel subfamily A member 1; CB1: cannabinoid receptor 1; NMDAR: N-Methy-D-Aspartate Receptor; ChemR23: chemerin receptor 23; LTP: long-term potentiation; TNF- $\alpha$ : Tumoral nuclear factor; IL-1b: Interleucin 1b; IL-6: Interleucin 6; PKC: protein kinase C; PKA: protein kinase A; ERK: extracellular signal-regulated kinase; MAPK: mitogen-activated protein kinases; JNK: JUN N-terminal kinase; NO: nitric oxide; sGC: soluble guanylyl cyclase receptor.

Following the development of CS, nociceptive neurons can potently signal to higherorder structures in the brain and brainstem, resulting in pathological pain perception. Furthermore, expansion of receptive fields is often observed, resulting in pain perception from stimulation of uninjured tissue, a phenomenon termed secondary hyperalgesia [84].

Numerous neurobiological mechanisms have been identified in this scenario. Following intense stimulation or persistent injury, activated $C$ and $A \delta$ fibers release a variety of neurotransmitters, including glutamate, substance $\mathrm{P}$, calcitonin gene-related peptide (CGRP), and ATP, onto output neurons of the superficial DH. In consequence, NMDA glutamate receptors (NMDAR) in postsynaptic neurons are activated, increasing intracellular calcium levels and activating a host of calcium-dependent signaling pathways and second messengers, such as mitogen-activated protein kinase (MAPK), protein kinase C (PKC), PKA, and Src [50]. In addition, the increase of the intracellular levels of calcium triggers a cascade of events that include activation of neuronal NO synthase (Nnos), followed by the increase of NO production. The subsequent activation of intracellular receptor soluble guanylyl cyclase (sGC), leads to the activation of the NO-cGMP signaling pathway, present in neurons of the spinal cord implicated in CS, secondary hyperalgesia, and modulation of ion channels. This cascade of events heightens the excitability of output neurons and facilitates the transmission of nociceptive signals to the brain [85]. 
SPMs regulate this aspect chiefly by interacting with TRPV1 and TRPA1 receptors [79,86-88]. Low-dose administration of MaR1 and PD1 can reduce TRPV1 activity in neurons in the dorsal roots ganglia (DRG), with their subsequent inhibition caused by PKA and ERK activity [86,87,89-93]. PD1 also decreases hyperexcitability by negatively regulating synaptic transmission induced by TNF- $\alpha$ and LTP in the spinal cord $[86,93]$. Moreover, RvD1, RvE1, RvD2, and ATL are also powerful TRPA1 and TRPV1 inhibitors [94]; and RvD1 can also suppress TRPV3 and TRPV4 activity [94-97]. These effects appear to converge in decreased glutamate release in presynaptic neurons, along with decreased ERK phosphorylation, NF- $\kappa$ B translocation, and TNF- $\alpha$ and IL-1 $\beta$ expression $[79,94,96,98]$. TRPV1 are colocalized with ChemP23 receptors in DRG neurons, which can decrease the hypersensitivity related to mechanical and thermal pain in advanced stages of inflammatory processes by binding RvD1 and RvE1 [79,99]. Similarly, AT-RvD1, another type of Rv, increases ChemR23 mRNA expression [100]. Rv may also modulate NMDAR involved in CS and LTP $[89,96]$.

Indeed, SPMs can modulate the activity of glutamate and NMDAR, which have been linked to hyperalgesia, neuropathic pain, and decreased opioid activity [101-103]. In particular, RvE1 can inhibit glutamate release in presynaptic terminals, and consequently reduce NMDAR-mediated potentiation by blocking phosphorylation in the ERK pathway. Importantly, this potentiation is associated with the development of changes in the amplitude and frequency of spontaneous excitatory postsynaptic currents (sEPCs), a neural phenomenon implicated in the processes underlying the neuroplasticity associated with CS and LTP. Therefore, decreasing glutamatergic activity may be a potential mechanism for reducing CP $[79,98]$. Likewise, RvD1 can prevent the phosphorylation of NMDAR and reduce the expression of proinflammatory cytokines, ameliorating allodynia [104].

Similarly, it has been demonstrated that when the $\mu$ opioid receptor is blocked, antinociception of RVD1 and its ligand TRPA1 is prevented. This supports the hypothesis of an imbalance in the endogenous pro and antinociceptive systems, or the TRPA1 and opioid receptors. However, increased research is needed to comprehend this phenomenon [105]. Interestingly, the activation of leukocyte-specific opioid receptors was recently reported to attenuate pain after nerve injury in mice by hyperpolarizing central and peripheral sensory neurons and diminishing the release of excitatory mediators from these neurons, including substance P [106,107], CGRP [108], and glutamate [109]. Indeed, convincing evidence delineates analgesic effects for opioid peptides derived from immune cells in both animal and human models [110-113].

Other receptors bear important implications in the resolution of inflammation and pain, including GPR37, GPR18, and GPR32. RvD1, RvD3, and RvD5 are ligands for the latter, whose inhibition is related to analgesic properties that could be sex-dependent $[114,115]$. On the other hand, activation of GPR37 by PD1 modulates macrophage-mediated phagocytosis by increasing intracellular calcium mobilization related to signal transduction mediated by Gi/o subunits, ERK and PI3K/AKT, all involved in the resolution of proinflammatory and neuropathic pain states [74,93,116,117]. Furthermore, PD1/GPR37 interactions potentiate the activity of M2 macrophages, in association with the release of $\beta$-endorphins $[118,119]$. On the other hand, GPR18 is a cannabinoid receptor whose ligand is RvD2, which, when activated, increases cAMP levels without changes in intracellular calcium traffic, downregulating various components related to CS such as TRP, MAPK, and JNK phosphorylation, as well as NMDAR [52,120]. Finally, LXA4 also acts as a positive allosteric modulator in CB1 receptors, reducing neuronal excitability [121]. It has been hypothesized that CB1 modulation could restore the levels of IL-1 $\beta$ and COX2 after inflammatory stimuli [122].

Glial cells play a key role as mediators for the neuroactive effects of SPMs [123,124]. Both microglia and astrocytes express specific receptors for SMP such as ALX/FPR2, which can inhibit phosphorylation and activation of MAPK such as p-p38, ERK, and JNK [125-130]. LX activity has been linked with increased SOCS-1 mRNA levels, which is related to decreased synthesis of pro-inflammatory cytokines induced by JAK-STAT $[131,132]$. 
Likewise, MaR1, PD1, RvD1, and RvD2 appear to reduce inflammatory pain by inactivating microglia and astrocytes through similar mechanisms, in addition to inhibiting nuclear translocation of NF- $\kappa$ B and the subsequent release of TNF- $\alpha$, IL-1 $1 \beta$, and IL- 6 in peripheral and central nociceptor neurons [131,132]. In turn, both microglia and astrocytes express GRP18 cannabinoid receptors. Their activation by RvD2 may be related to PI3K/AKT/GSK-3 $\beta$ pathway inactivation, triggering inhibition of NF- $\mathrm{KB}$ and the release of anti-inflammatory substances such as TGF- $\beta 1$ in the spinal cord [133]. On the other hand, PD1, LXA4, and MaR1 can decrease the expression of IBA-1 and P2Y12 in microglia and GFAP in astrocytes, with amelioration of mechanical allodynia and thermal hyperalgesia $[14,134,135]$.

Moreover, IL-1 $\beta$ also appears to promote BDNF release in enteric glial cells in subjects with irritable bowel syndrome [136]; and levels of this cytokine have also been correlated with the severity and frequency of abdominal pain in this context [137]. The contribution of astrocytes to CS is less clear [10,77]; although they are also activated after spinal cord injury. This process is typically delayed, yet more persistent, and it can last for up to several months. Thus, astrocytes may be more critical to the maintenance, rather than the induction of CS and persistent pain [77].

Likewise, ATP and the chemokine fractalkine (CXCL1) released from nociceptive fibers may also contribute to CS, through the stimulation of spinal microglia. ATP mainly targets microglial P2-type purinergic receptors, triggering the release of brain-derived neurotrophic factor (BDNF). In turn, this activates TrkB in output receptors in lamina I neurons at the $\mathrm{DH}$-a process facilitated by IFN- $\gamma$ in rodents [138] — which markedly changes chloride ion traffic in these neurons, facilitating depolarization, and thus, increasing excitability and decreasing the response threshold to both noxious and innocuous stimuli [139]. Activation of fractalkine receptor CX3CR1 and Toll-like receptors in microglia also induces the release of BDNF and various cytokines in the spinal cord, favoring CS [140,141].

Oxidative stress, an essential characteristic of neuroinflammatory states, is also targeted by SPMs. LXA4 can increase Nrf2 expression and heme oxygenase translocation to the nucleus [142]; while ATL inhibit the translocation of p47phox to the cell membrane, resulting in lower NADPH oxidase activity and decreased ROS formation by BV2 microglia [143]. In these cells, RvE1 and RvE2 can compete with chemerin for ChemR23 receptors, attenuating pro-inflammatory activity $[79,99,116,144]$. Likewise, LXA4 may increase superoxide dismutase activity [145]; similarly to MaR1 and RvD1, which appear to upregulate glutathione peroxidase [146].

On the other hand, PD1 can suppress the activity of the transcription activating factor 3 (ATF3), which is associated with axonal lesions in DRG and the development of neuropathies [134,147]. In addition, MaR1 exerts neuroprotective effects against oxidative stress by inducing the expression of SOD1 G93AA315T and TDP-43A315T [148]. Lastly, 17-oxoDHA, a metabolite of 17-HDHA, acts as an agonist of peroxisome proliferatoractivated receptors (PPAR) $\alpha$ and $\gamma$, which appear to have anti-nociceptive effects by lowering LTB4 levels, augmenting LXA4 synthesis and facilitating nitric oxide activity $[11,149,150]$.

\subsection{Preclinical and Clinical Evidence on Specialized Pro-Resolving Lipids Mediators in the Management of Pain}

In light of the many mechanistic links between SPMs and the pathophysiology of $\mathrm{CP}$, their potential for clinical use has become a key emergent object of research. Preclinical data underlines the efficacy of LX in various animal models of pain, including chronic post-ischemic pain (CPIP) [151], carrageenan-elicited pain (CEP) [127,152], bone cancer-induced pain (BCIP) [130], spinal cord injury (SCI) $[15,129,153]$, chronic constriction injury (CCI) [154], chronic compression of the dorsal root ganglion (CCD) [155], and non-compressive lumbar disc herniation [128].

Notably, in a recent study by Liu et al., BML-111—an LXA4 receptor agonist—was used in rats with SCI, resulting in significantly lower levels of TNF- $\alpha$, IL-1 $\beta$, and IL-6 in serum and spinal cord tissue [129]. Sun et al. reported similar results in CCD models, where LXA4 reduced mechanical hypersensitivity in association with decreased TNF- $\alpha$, 
IL1 $\beta$, and IL-6 [155]. Treatment with LXA4 and LXB4 has also been described to reduce mechanical allodynia in rats with BCIP [130]; and LXA4, LXB4, and AT-LXA4 appear to reduce mechanical hypersensitivity in carrageenan-treated rats $[127,152]$. Besides, treatment with AT-LXA4 has been reported to decrease chronic morphine-induced thermal hyperalgesia by blocking NALP1-derived IL- $1 \beta$ levels in vivo and in vitro, pinpointing a promising pharmacological target for the treatment of pain [156].

Regarding SPMs derived from DPA and DHA, many studies have shown efficacy for RvD, PD, and MaR in animal models of pain, such as CCI [134], formalin-induced pain (FIP) $[79,93,94,96]$, capsaicin-induced pain $[89,93,94]$, complete Freund's adjuvant (CFA)-induced pain [79,93,94,96,105], osteoarthritis pain [95], and CEP pain [79,93,100,152]. They may also intervene significantly in temporomandibular joint inflammatory pain [92], CPIP [151], chronic post-thoracotomy pain (CPTP) [120,157], post-operative pain induced by tibial bone fracture (PTBF) [133], herniation-induced radicular pain [158], chronic pancreatitis-induced visceral pain [104], and peripheral neuropathic pain induced by chemotherapy (PNPC) [114].

A study performed by Zhang et al. evaluated intravenous perioperative treatment with DHA (500 $\mu \mathrm{g}), \mathrm{RvD1}(500 \mathrm{ng})$, and MaR1 (500 ng) on a mouse model of PNPC, revealing efficacy for these alternatives in pain prevention and delay. They may also alleviate established pain, though this remains less clear [159]. Likewise, RvD2 has been reported to reduce heat hyperalgesia, mechanical allodynia, second-phase spontaneous pain, and thermal sensitization in FIP, CEP, capsaicin-induced pain, AITC, CFA, and fibromyalgia-like pain [94,160]. Conversely, Luo et al. did not find analgesic effects with intrathecal administration of RvD3 and $\mathrm{RvD}$ and reported a reduction in mechanical hyperalgesia with RvD5 treatment only in CIPN male mice [114].

Finally, RvE has also been found effective in animal models of CFA-induced inflammatory pain [79,161], FIP [37,161], CEP [79,161], CCI [123], and spinal nerve injury (SNI) [123]. Indeed, in an equivalent dose 1000 times lower than morphine, RvE1 appears to reduce second-phase spontaneous pain in FIP models [79]. Furthermore, in two studies, $\mathrm{Xu}$ et al. reported a decrease in mechanical allodynia, heat hyperalgesia, edema, neutrophil infiltration, and expression of pro-inflammatory cytokines and chemokines in diverse pain models treated with RvE1 [79,123]. This is notable, since RvE1 has been shown to be significantly increased by $\mathrm{n}-3$ fatty acids supplementation in humans [162]. Even though effective in reducing inflammation, no robust analgesic effects have been described for RvE2 and RvE3 $[163,164]$. On the other hand, a phase 2 study examined the therapeutic effectivity of RX-10045, a synthetic analog of RvE1, in the treatment of eye inflammation and pain in cataract surgery [165].

Beyond mechanistic and animal studies, SPMs have also been tested as analgesics in humans with various pain-related conditions (Table 1), such as chronic headaches [166], migraines [167], joint discomfort [15,168], sickle cell disease [169], diabetic neuropathy [170], and various rheumatic diseases $[15,171-175]$. Firstly, supplementation with certain doses of $\omega-3$ PUFAs appears to produce an increase in circulating anti-inflammatory mediators in humans [176]. For example, in a meta-analysis by Goldberg et al. [15] included 17 trials evaluating the pain-relieving effects of $\omega-3$ PUFA in patients with rheumatoid arthritis or joint pain related to inflammatory bowel disease and dysmenorrhea. The researchers found that supplementation reduced patient-reported joint pain intensity (SMD: -0.26 ; $95 \%$ CI: -0.49 to $-0.03, p=0.03$ ), minutes of morning stiffness (SMD: $-0.43 ; 95 \%$ CI: -0.72 to $-0.15, p=0.003$ ), number of painful and/or tender joints (SMD: $-0.29 ; 95 \% \mathrm{CI}:-0.48$ to $-0.10, p=0.003$ ), and NSAID use (SMD: $-0.40 ; 95 \%$ CI: -0.72 to $-0.08, p=0.01$ ). 
Table 1. Summary of critical clinical evidence regarding specialized pro-resolving lipid mediators and pain-related conditions.

\begin{tabular}{|c|c|c|c|}
\hline Authors (REF) & Pain-Related Conditions & Methodology & Results \\
\hline Goldberg et al. [15] & $\begin{array}{c}\text { Rheumatoid arthritis and } \\
\text { joint pain }\end{array}$ & $\begin{array}{l}\text { Meta-analysis with } 17 \\
\text { randomized controlled clinical } \\
\text { trials evaluating the } \\
\text { pain-relieving effects of } \omega-3 \text { PUFA } \\
\text { in patients with rheumatoid } \\
\text { arthritis or joint pain related to } \\
\text { inflammatory bowel disease } \\
\text { and dysmenorrhea. }\end{array}$ & $\begin{array}{l}\text { Treatment with } \omega-3 \text { PUFA for } 3-4 \\
\text { months reduced patient-reported } \\
\text { joint pain intensity (SMD: }-0.26 \text {; } \\
95 \% \text { CI: }-0.49 \text { to }-0.03, p=0.03 \text { ), } \\
\text { minutes of morning stiffness (SMD: } \\
\quad-0.43 ; 95 \% \text { CI: }-0.72 \text { to }-0.15 \\
\quad p=0.003), \text { number of painful } \\
\text { and /or tender joints (SMD: }-0.29 ; \\
95 \% \text { CI: }-0.48 \text { to }-0.10, p=0.003 \text { ), } \\
\text { and NSAID use (SMD: }-0.40 ; 95 \% \\
\text { CI: }-0.72 \text { to }-0.08, p=0.01)\end{array}$ \\
\hline Geusens et al. [173] & Rheumatoid arthritis & $\begin{array}{l}\text { Randomized, double-blind } \\
\text { controlled trial that assessed the } \\
\text { long-term effects of } \\
\text { supplementation with various } \\
\text { doses of } \omega-3 \text { PUFA in } 90 \text { patients } \\
\text { with active rheumatoid arthritis. }\end{array}$ & $\begin{array}{l}\text { There was a significant } \\
\text { improvement in the patient's global } \\
\text { evaluation and the physician's } \\
\text { assessment of pain in patients } \\
\text { treated with } 2.6 \mathrm{mg} / \text { day of } \omega-3 \\
(p<0.05) .\end{array}$ \\
\hline Tajmirriahi et al. [167] & Migraine & $\begin{array}{l}\text { Randomized, single-blind clinical } \\
\text { trial that evaluated the effect of } \\
\text { dietary supplementation with fish } \\
\text { oil for migraine prevention in } \\
67 \text { patients taking } \\
\text { sodium valproate. }\end{array}$ & $\begin{array}{l}\text { There was a significant decrease in } \\
\text { frequency (mean baseline from } 13.7 \\
\text { to } 2.4 ; p=0.044 \text { ), and severity of } \\
\text { migraines (mean baseline from } 7.9 \\
\text { to } 2.9 ; p=0.046 \text { ) in participants } \\
\text { treated with sodium valproate and } \\
\text { fish oil supplementation after the } \\
\text { first month of treatment. }\end{array}$ \\
\hline Tomer et al. [169] & Sickle cell disease & $\begin{array}{l}\text { A double-blind clinical trial that } \\
\text { assessed the effects of dietary } \omega-3 \\
\text { PUFA on the frequency of pain } \\
\text { episodes in patients with sickle } \\
\text { cell disease in comparison with } \\
\text { controls on olive oil. }\end{array}$ & $\begin{array}{l}\text { Treatment with dietary } \omega-3 \text { PUFA } \\
\text { for } 1 \text { year reduced the frequency of } \\
\text { pain episodes }(p<0.01) .\end{array}$ \\
\hline Durán et al. [170] & Diabetic neuropathy & $\begin{array}{l}\text { Interventional single-group study } \\
\text { to assess the efficacy of dietary } \\
\omega-3 \text { PUFA in } 40 \text { participants with } \\
\text { type } 2 \text { diabetes. }\end{array}$ & $\begin{array}{l}\text { There was a significant reduction in } \\
\text { pain-related neuropathy symptoms } \\
\text { after three months of treatment } \\
\text { with } \omega-3 \text { PUFA (change from } \\
\text { baseline }-2.1(p=0.014) \text { and } \\
-9.2(p=0.002)) .\end{array}$ \\
\hline Ramsden et al. [166] & Chronic headache & $\begin{array}{l}\text { Randomized, parallel-group and } \\
\text { 12-week trial designed to test the } \\
\text { clinical effects of a diet high in } \\
\omega-3 \text { and low in } \omega-6 \text { PUFA } \\
\text { compared to a diet low in } \omega-6 \\
\text { PUFA in } 67 \text { subjects with } \\
\text { chronic headaches. }\end{array}$ & $\begin{array}{l}\text { There was reduction of pain } \\
\text { frequency }(p<0.001) \text {, intensity } \\
(p<0.001) \text {, and psychological } \\
\text { distress }(p=0.022) \text { in patients } \\
\text { treated with a diet high in } \omega-3 \text { and } \\
\text { low in } \omega-6 \text { PUFA. }\end{array}$ \\
\hline
\end{tabular}

Abbreviations: PUFA: polyunsaturated fatty acids; NSAID: non-steroidal anti-inflammatory drugs.

Likewise, a 12-month, double-blind, controlled study compared daily supplementation with various doses of $\omega-3$ PUFA, reporting significant improvement in patients' global evaluation and physicians' assessment of pain in those taking doses of $2.6 \mathrm{mg} /$ day. This group also significantly reduced the use of anti-rheumatic medications [173]. Similarly, in a randomized, double-blind, placebo-controlled trial fish oil with $\omega-3$ PUFA reduced symptoms of pain and stiffness significantly after nine weeks of treatment were observed [168]. In the "En Balance-Plus" study, an interventional study designed to assess the efficacy of dietary $\omega-3$ PUFA in diabetic patients, significant reductions in pain-related neuropathy symptoms were reported after three months [170]. A randomized, parallel-group, 12-weeks trial with a diet high in $\omega-3$ fatty acids and low in $\omega-6$ PUFA demonstrated a reduction in pain frequency, intensity, and psychological distress in patients with chronic 
headaches [166]. Various other clinical trials have evaluated the use of PUFA in conditions such as pediatric sickle-cell anemia [177], post-traumatic headache [178], fibromyalgia [179], among others [180-182], with promising results. Although these effects may not be wholly attributed to SPM-with changes in sphingolipid metabolism also playing a purportedly significant part-their significance in this context is notable.

\section{Conclusions}

Currently, CP remains one of the most prevalent clinical entities in clinical medicine, related to a wide range of diseases. In response, in recent years there has been a search for novel alternatives for its management. SPMs stand out in this scenario as a group of bioactive lipids which play a fundamental role in the resolution of inflammation and can ameliorate $\mathrm{CP}$ through various mechanisms.

These molecules have immunomodulatory properties which can diminish inflammation associated with peripheral and central nociception. Abundant preclinical and clinical evidence supports the role of SPMs in neuroinflammation associated with CS and LTP, either through the modulation of microglia, the regulation of nociceptors, or the regulation of the neuronal pathways implicated in pain.

Nevertheless, further high-quality studies are necessary to better characterize the clinical utility of SPMs in CP, especially attending to the large variety of etiologies, pathophysiologic mechanisms, and clinical presentations that may be associated with this entity. Likewise, deeper research in this area would allow the assessment of adverse effects, tolerability and pharmacological interactions of SPMs. Continued investigation in this field is worthwhile, as SPMs could prove to be an invaluable treatment tool in the future.

Author Contributions: Conceptualization, M.C.-C., Á.O., P.D., J.B.D.S. and V.B.; investigation, P.D., Á.O., M.C.-C., A.M., A.S., L.C.-T. and B.G.; writing-original draft, P.D., Á.O., M.C.-C., A.M., A.S., D.M.R.-G. and B.G.; writing-review and editing, M.R., J.B.D.S., V.B., J.S., D.M.R.-G. and M.C.-C.; funding acquisition V.B. and L.C.-T. All authors have read and agreed to the published version of the manuscript.

Funding: This work was supported by research grant no. CC-0437-10-21-09-10 from Consejo de Desarrollo Científico, Humanístico y Tecnológico (CONDES), University of Zulia, and research grant no. FZ-0058-2007 from Fundacite-Zulia.

Institutional Review Board Statement: Not applicable.

Informed Consent Statement: Not applicable.

Data Availability Statement: Not applicable.

Conflicts of Interest: The authors declare no conflict of interest.

\section{References}

1. Geurts, J.W.; Willems, P.C.; Lockwood, C.; van Kleef, M.; Kleijnen, J.; Dirksen, C. Patient Expectations for Management of Chronic Non-Cancer Pain: A Systematic Review. Health Expect. 2017, 20, 1201-1217. [CrossRef]

2. GBD 2016 Disease and Injury Incidence and Prevalence Collaborators. Global, Regional, and National Incidence, Prevalence, and Years Lived with Disability for 328 Diseases and Injuries for 195 Countries, 1990-2016: A Systematic Analysis for the Global Burden of Disease Study 2016. Lancet 2017, 390, 1211-1259. [CrossRef]

3. Fayaz, A.; Croft, P.; Langford, R.M.; Donaldson, L.J.; Jones, G.T. Prevalence of Chronic Pain in the UK: A Systematic Review and Meta-Analysis of Population Studies. BMJ Open 2016, 6, e010364. [CrossRef] [PubMed]

4. Kheiry, F.; Rakhshan, M.; Shaygan, M. The prevalence and associated factors of chronic pain in nurses Iran. Latinoam. Hipertens. 2019, 14, 20-25.

5. Dahlhamer, J.; Lucas, J.; Zelaya, C.; Nahin, R.; Mackey, S.; DeBar, L.; Kerns, R.; Von Korff, M.; Porter, L.; Helmick, C. Prevalence of Chronic Pain and High-Impact Chronic Pain Among Adults-United States, 2016. MMWR Morb. Mortal. Wkly. Rep. 2018, 67, 1001-1006. [CrossRef] [PubMed]

6. De La Cruz, V.J.A.; Dos Santos, F.; Dyzinger, W.; Herzog, S. Medicina Del Estilo de Vida: Trabajando Juntos Para Revertir La Epidemia de Las Enfermedades Crónicas En Latinoamérica. Cienc. Innovación Salud 2017, 4, 1-7. [CrossRef]

7. World Health Organization. Opioid Overdose. Available online: https://www.who.int/news-room/fact-sheets/detail/opioidoverdose (accessed on 21 June 2021). 
8. Hern, O.; Saumeth, K.T.; Cabrera, J.L.; Pinz, M. Consumos y Costos de Medicamentos: Herramienta para la Gestión de Suministro del Servicio Farmacéutico. Cienc. Innovación Salud 2015, 3, 45-52. [CrossRef]

9. $\quad$ Freire, L.F.L.; Chingo, D.J.A.; Saldarriaga, L.C.Z.; Mera, L.M.I.; Escalante, V.C.G.; Villacres, A.X.Z.; Sanguil, A.T.A.; Bucheli, F.J.J.; Velasco, S.J.S. Alternativas emergentes en la farmacoterapia de la neuralgia del trigémino. AVFT-Arch. Venez. Farmacol. Ter. 2019, $38,34-39$.

10. Ji, R.-R.; Xu, Z.-Z.; Gao, Y.-J. Emerging Targets in Neuroinflammation-Driven Chronic Pain. Nat. Rev. Drug Discov. 2014, 13, 533-548. [CrossRef]

11. Valdes, A.M.; Ravipati, S.; Menni, C.; Abhishek, A.; Metrustry, S.; Harris, J.; Nessa, A.; Williams, F.M.K.; Spector, T.D.; Doherty, M.; et al. Association of the Resolvin Precursor 17-HDHA, but Not D- or E- Series Resolvins, with Heat Pain Sensitivity and Osteoarthritis Pain in Humans. Sci. Rep. 2017, 7, 10748. [CrossRef]

12. Chiang, N.; Serhan, C.N. Structural Elucidation and Physiologic Functions of Specialized Pro-Resolving Mediators and Their Receptors. Mol. Asp. Med. 2017, 58, 114-129. [CrossRef]

13. Fattori, V.; Zaninelli, T.H.; Rasquel-Oliveira, F.S.; Casagrande, R.; Verri, W.A. Specialized Pro-Resolving Lipid Mediators: A New Class of Non-Immunosuppressive and Non-Opioid Analgesic Drugs. Pharmacol. Res. 2020, 151, 104549. [CrossRef] [PubMed]

14. Martini, A.C.; Berta, T.; Forner, S.; Chen, G.; Bento, A.F.; Ji, R.-R.; Rae, G.A. Lipoxin A4 Inhibits Microglial Activation and Reduces Neuroinflammation and Neuropathic Pain after Spinal Cord Hemisection. J. Neuroinflamm. 2016, 13, 75. [CrossRef]

15. Goldberg, R.J.; Katz, J. A Meta-Analysis of the Analgesic Effects of Omega-3 Polyunsaturated Fatty Acid Supplementation for Inflammatory Joint Pain. Pain 2007, 129, 210-223. [CrossRef] [PubMed]

16. Calder, P.C. Polyunsaturated Fatty Acids and Inflammatory Processes: New Twists in an Old Tale. Biochimie 2009, 91, 791-795. [CrossRef]

17. Zhang, L.-Y.; Jia, M.-R.; Sun, T. The Roles of Special Proresolving Mediators in Pain Relief. Rev. Neurosci. 2018, 29, 645-660. [CrossRef] [PubMed]

18. Schaller, M.S.; Zahner, G.J.; Gasper, W.J.; Harris, W.S.; Conte, M.S.; Hills, N.K.; Grenon, S.M. Relationship between the Omega-3 Index and Specialized pro-Resolving Lipid Mediators in Patients with Peripheral Arterial Disease Taking Fish Oil Supplements. J. Clin. Lipidol. 2017, 11, 1289-1295. [CrossRef]

19. Levy, B.D. Resolvins and Protectins: Natural Pharmacophores for Resolution Biology. Prostaglandins Leukot. Essent. Fatty Acids 2010, 82, 327-332. [CrossRef]

20. Patrignani, P.; Patrono, C. Cyclooxygenase Inhibitors: From Pharmacology to Clinical Read-Outs. Biochim. Biophys. Acta (BBA) Mol. Cell Biol. Lipids 2015, 1851, 422-432. [CrossRef]

21. Serhan, C.N. Pro-Resolving Lipid Mediators Are Leads for Resolution Physiology. Nature 2014, 510, 92-101. [CrossRef]

22. Recchiuti, A.; Serhan, C.N. Pro-Resolving Lipid Mediators (SPMs) and Their Actions in Regulating MiRNA in Novel Resolution Circuits in Inflammation. Front. Immunol. 2012, 3, 298. [CrossRef] [PubMed]

23. Dalli, J.; Serhan, C.N. Pro-Resolving Mediators in Regulating and Conferring Macrophage Function. Front. Immunol. 2017, 8 , 1400. [CrossRef]

24. Serhan, C.N. Resolution Phase of Inflammation: Novel Endogenous Anti-Inflammatory and Proresolving Lipid Mediators and Pathways. Annu. Rev. Immunol. 2007, 25, 101-137. [CrossRef] [PubMed]

25. Levy, B.D.; Clish, C.B.; Schmidt, B.; Gronert, K.; Serhan, C.N. Lipid Mediator Class Switching during Acute Inflammation: Signals in Resolution. Nat. Immunol. 2001, 2, 612-619. [CrossRef]

26. Serhan, C.N.; Levy, B.D. Resolvins in Inflammation: Emergence of the pro-Resolving Superfamily of Mediators. J. Clin. Investig. 2018, 128, 2657-2669. [CrossRef] [PubMed]

27. Serhan, C.N.; Chiang, N.; Dalli, J.; Levy, B.D. Lipid Mediators in the Resolution of Inflammation. Cold Spring Harb. Perspect. Biol. 2014, 7, a016311. [CrossRef]

28. Fiore, S.; Ryeom, S.W.; Weller, P.F.; Serhan, C.N. Lipoxin Recognition Sites. Specific Binding of Labeled Lipoxin A4 with Human Neutrophils. J. Biol. Chem. 1992, 267, 16168-16176. [CrossRef]

29. Minciullo, P.L.; Catalano, A.; Mandraffino, G.; Casciaro, M.; Crucitti, A.; Maltese, G.; Morabito, N.; Lasco, A.; Gangemi, S.; Basile, G. Inflammaging and Anti-Inflammaging: The Role of Cytokines in Extreme Longevity. Arch. Immunol. Ther. Exp. 2016, 64, 111-126. [CrossRef] [PubMed]

30. Serhan, C.N.; Krishnamoorthy, S.; Recchiuti, A.; Chiang, N. Novel Anti-Inflammatory-pro-Resolving Mediators and Their Receptors. Curr. Top. Med. Chem. 2011, 11, 629-647. [CrossRef]

31. McMahon, B.; Godson, C. Lipoxins: Endogenous Regulators of Inflammation. Am. J. Physiol. Renal Physiol. 2004, 286, F189-F201. [CrossRef]

32. Kang, Y.; Taddeo, B.; Varai, G.; Varga, J.; Fiore, S. Mutations of Serine 236-237 and Tyrosine 302 Residues in the Human Lipoxin A4 Receptor Intracellular Domains Result in Sustained Signaling. Biochemistry 2000, 39, 13551-13557. [CrossRef]

33. Bonnekoh, H.; Scheffel, J.; Wu, J.; Hoffmann, S.; Maurer, M.; Krause, K. Skin and Systemic Inflammation in Schnitzler's Syndrome Are Associated With Neutrophil Extracellular Trap Formation. Front. Immunol. 2019, 10, 546. [CrossRef]

34. Barbu, E.A.; Mendelsohn, L.; Samsel, L.; Thein, S.L. Pro-Inflammatory Cytokines Associate with NETosis during Sickle Cell Vaso-Occlusive Crises. Cytokine 2020, 127, 154933. [CrossRef]

35. Li, X.; Yuan, K.; Zhu, Q.; Lu, Q.; Jiang, H.; Zhu, M.; Huang, G.; Xu, A. Andrographolide Ameliorates Rheumatoid Arthritis by Regulating the Apoptosis-NETosis Balance of Neutrophils. Int. J. Mol. Sci. 2019, 20, 5035. [CrossRef] [PubMed] 
36. Headland, S.E.; Norling, L.V. The Resolution of Inflammation: Principles and Challenges. Semin. Immunol. 2015, $27,149-160$. [CrossRef] [PubMed]

37. Romano, M.; Cianci, E.; Simiele, F.; Recchiuti, A. Lipoxins and Aspirin-Triggered Lipoxins in Resolution of Inflammation. Eur. J. Pharmacol. 2015, 760, 49-63. [CrossRef]

38. Chiang, N.; Bermudez, E.A.; Ridker, P.M.; Hurwitz, S.; Serhan, C.N. Aspirin Triggers Antiinflammatory 15-Epi-Lipoxin A4 and Inhibits Thromboxane in a Randomized Human Trial. Proc. Natl. Acad. Sci. USA 2004, 101, 15178-15183. [CrossRef] [PubMed]

39. Serhan, C.N.; Chiang, N.; Van Dyke, T.E. Resolving Inflammation: Dual Anti-Inflammatory and pro-Resolution Lipid Mediators. Nat. Rev. Immunol. 2008, 8, 349-361. [CrossRef] [PubMed]

40. O'Meara, S.J.; Rodgers, K.; Godson, C. Lipoxins: Update and Impact of Endogenous pro-Resolution Lipid Mediators. Rev. Physiol. Biochem. Pharmacol. 2008, 160, 47-70. [CrossRef]

41. Recchiuti, A.; Mattoscio, D.; Isopi, E. Roles, Actions, and Therapeutic Potential of Specialized Pro-Resolving Lipid Mediators for the Treatment of Inflammation in Cystic Fibrosis. Front. Pharmacol. 2019, 10, 252. [CrossRef]

42. Ryan, A.; Godson, C. Lipoxins: Regulators of Resolution. Curr. Opin. Pharmacol. 2010, 10, 166-172. [CrossRef]

43. Maderna, P.; Cottell, D.C.; Berlasconi, G.; Petasis, N.A.; Brady, H.R.; Godson, C. Lipoxins Induce Actin Reorganization in Monocytes and Macrophages but Not in Neutrophils: Differential Involvement of Rho GTPases. Am. J. Pathol. 2002, 160, 2275-2283. [CrossRef]

44. Levy, B.D.; Serhan, C.N. Resolution of Acute Inflammation in the Lung. Annu. Rev. Physiol. 2014, 76, 467-492. [CrossRef] [PubMed]

45. Serhan, C.N.; Savill, J. Resolution of Inflammation: The Beginning Programs the End. Nat. Immunol. 2005, 6, 1191-1197. [CrossRef] [PubMed]

46. Dalli, J.; Serhan, C. Macrophage Proresolving Mediators-the When and Where. Microbiol. Spectr. 2016, 4. [CrossRef] [PubMed]

47. Ariel, A.; Chiang, N.; Arita, M.; Petasis, N.A.; Serhan, C.N. Aspirin-Triggered Lipoxin A4 and B4 Analogs Block Extracellular Signal-Regulated Kinase-Dependent TNF-Alpha Secretion from Human T Cells. J. Immunol. 2003, 170, 6266-6272. [CrossRef] [PubMed]

48. Chiurchiù, V.; Leuti, A.; Maccarrone, M. Bioactive Lipids and Chronic Inflammation: Managing the Fire Within. Front. Immunol. 2018, 9, 38. [CrossRef] [PubMed]

49. Tungen, J.E.; Gerstmann, L.; Vik, A.; De Matteis, R.; Colas, R.A.; Dalli, J.; Chiang, N.; Serhan, C.N.; Kalesse, M.; Hansen, T.V. Resolving Inflammation: Synthesis, Configurational Assignment, and Biological Evaluations of RvD1n-3 DPA. Chemistry 2019, 25, 1476-1480. [CrossRef]

50. Latremoliere, A.; Woolf, C.J. Central Sensitization: A Generator of Pain Hypersensitivity by Central Neural Plasticity. J. Pain 2009, 10, 895-926. [CrossRef]

51. Christensen, J.E.; Andreasen, S.O.; Christensen, J.P.; Thomsen, A.R. CD11b Expression as a Marker to Distinguish between Recently Activated Effector CD8(+) T Cells and Memory Cells. Int. Immunol. 2001, 13, 593-600. [CrossRef]

52. Chiang, N.; Dalli, J.; Colas, R.A.; Serhan, C.N. Identification of Resolvin D2 Receptor Mediating Resolution of Infections and Organ Protection. J. Exp. Med. 2015, 212, 1203-1217. [CrossRef]

53. Chiang, N.; de la Rosa, X.; Libreros, S.; Serhan, C.N. Novel Resolvin D2 Receptor Axis in Infectious Inflammation. J. Immunol. 2017, 198, 842-851. [CrossRef]

54. Duffney, P.F.; Falsetta, M.L.; Rackow, A.R.; Thatcher, T.H.; Phipps, R.P.; Sime, P.J. Key Roles for Lipid Mediators in the Adaptive Immune Response. J. Clin. Investig. 2018, 128, 2724-2731. [CrossRef]

55. Kim, N.; Ramon, S.; Thatcher, T.H.; Woeller, C.F.; Sime, P.J.; Phipps, R.P. Specialized Proresolving Mediators (SPMs) Inhibit Human B-Cell IgE Production. Eur. J. Immunol. 2016, 46, 81-91. [CrossRef]

56. Chen, G.; Zhang, Y.-Q.; Qadri, Y.J.; Serhan, C.N.; Ji, R.-R. Microglia in Pain: Detrimental and Protective Roles in Pathogenesis and Resolution of Pain. Neuron 2018, 100, 1292-1311. [CrossRef]

57. Dartt, D.A.; Hodges, R.R.; Serhan, C.N. Immunoresolvent Resolvin D1 Maintains the Health of the Ocular Surface. Adv. Exp. Med. Biol. 2019, 1161, 13-25. [CrossRef]

58. Spite, M.; Norling, L.V.; Summers, L.; Yang, R.; Cooper, D.; Petasis, N.A.; Flower, R.J.; Perretti, M.; Serhan, C.N. Resolvin D2 Is a Potent Regulator of Leukocytes and Controls Microbial Sepsis. Nature 2009, 461, 1287-1291. [CrossRef] [PubMed]

59. Mariani, F.; Roncucci, L. Chemerin/ChemR23 Axis in Inflammation Onset and Resolution. Inflamm. Res. 2015, 64, 85-95. [CrossRef]

60. Haworth, O.; Cernadas, M.; Levy, B.D. NK Cells Are Effectors for Resolvin E1 in the Timely Resolution of Allergic Airway Inflammation. J. Immunol. 2011, 186, 6129-6135. [CrossRef] [PubMed]

61. Serhan, C.N. Discovery of Specialized Pro-Resolving Mediators Marks the Dawn of Resolution Physiology and Pharmacology. Mol. Asp. Med. 2017, 58,1-11. [CrossRef] [PubMed]

62. Saeki, K.; Yokomizo, T. Identification, Signaling, and Functions of LTB4 Receptors. Semin. Immunol. 2017, 33, 30-36. [CrossRef] [PubMed]

63. Wu, C.; Sun, A.; Zou, Y.; Ge, J. "Pro-Resolution" and Anti-Inflammation, a Role of RvE1 in Anti-Atherosclerosis and Plaque Stabilization. Med. Hypotheses 2008, 71, 252-255. [CrossRef]

64. Buckley, C.D.; Gilroy, D.W.; Serhan, C.N. Proresolving Lipid Mediators and Mechanisms in the Resolution of Acute Inflammation. Immunity 2014, 40, 315-327. [CrossRef] 
65. Correa, M.D.; López, M.R. Activación alternativa del macrófago: La diversidad en las respuestas de una célula de la inmunidad innata ante la complejidad de los eventos de su ambiente. Inmunologia 2007, 26, 73-86. [CrossRef]

66. Serhan, C.N.; Dalli, J.; Colas, R.A.; Winkler, J.W.; Chiang, N. Protectins and Maresins: New pro-Resolving Families of Mediators in Acute Inflammation and Resolution Bioactive Metabolome. Biochim. Biophys. Acta 2015, 1851, 397-413. [CrossRef]

67. Tang, S.; Wan, M.; Huang, W.; Stanton, R.C.; Xu, Y. Maresins: Specialized Proresolving Lipid Mediators and Their Potential Role in Inflammatory-Related Diseases. Mediat. Inflamm. 2018, 2018, 2380319. [CrossRef]

68. Hwang, S.-M.; Chung, G.; Kim, Y.H.; Park, C.-K. The Role of Maresins in Inflammatory Pain: Function of Macrophages in Wound Regeneration. Int. J. Mol. Sci. 2019, 20, 5849. [CrossRef] [PubMed]

69. Häcker, H.; Karin, M. Regulation and Function of IKK and IKK-Related Kinases. Sci. STKE 2006, 2006, re13. [CrossRef]

70. Bitto, A.; Minutoli, L.; David, A.; Irrera, N.; Rinaldi, M.; Venuti, F.S.; Squadrito, F.; Altavilla, D. Flavocoxid, a Dual Inhibitor of COX-2 and 5-LOX of Natural Origin, Attenuates the Inflammatory Response and Protects Mice from Sepsis. Crit. Care 2012, 16, R32. [CrossRef]

71. Kohli, P.; Levy, B.D. Resolvins and Protectins: Mediating Solutions to Inflammation. Br. J. Pharmacol. 2009, 158, 960-971. [CrossRef] [PubMed]

72. Serhan, C.N. Novel Chemical Mediators in the Resolution of Inflammation: Resolvins and Protectins. Anesthesiol. Clin. 2006, 24, 341-364. [CrossRef] [PubMed]

73. Kytikova, O.; Novgorodtseva, T.; Denisenko, Y.; Antonyuk, M.; Gvozdenko, T. Pro-Resolving Lipid Mediators in the Pathophysiology of Asthma. Medicina 2019, 55, 284. [CrossRef] [PubMed]

74. Bang, S.; Xie, Y.-K.; Zhang, Z.-J.; Wang, Z.; Xu, Z.-Z.; Ji, R.-R. GPR37 Regulates Macrophage Phagocytosis and Resolution of Inflammatory Pain. J. Clin. Investig. 2018, 128, 3568-3582. [CrossRef]

75. Freire, M.O.; Van Dyke, T.E. Natural Resolution of Inflammation. Periodontology 2000 2013, 63, 149-164. [CrossRef]

76. Totsch, S.K.; Sorge, R.E. Immune System Involvement in Specific Pain Conditions. Mol. Pain 2017, 13, 1744806917724559. [CrossRef]

77. Chavan, S.S.; Pavlov, V.A.; Tracey, K.J. Mechanisms and Therapeutic Relevance of Neuro-Immune Communication. Immunity 2017, 46, 927-942. [CrossRef] [PubMed]

78. Cury, Y.; Picolo, G.; Gutierrez, V.P.; Ferreira, S.H. Pain and Analgesia: The Dual Effect of Nitric Oxide in the Nociceptive System. Nitric Oxide 2011, 25, 243-254. [CrossRef]

79. Xu, Z.-Z.; Zhang, L.; Liu, T.; Park, J.Y.; Berta, T.; Yang, R.; Serhan, C.N.; Ji, R.-R. Resolvins RvE1 and RvD1 Attenuate Inflammatory Pain via Central and Peripheral Actions. Nat. Med. 2010, 16, 592-597. [CrossRef] [PubMed]

80. Herová, M.; Schmid, M.; Gemperle, C.; Hersberger, M. ChemR23, the Receptor for Chemerin and Resolvin E1, Is Expressed and Functional on M1 but Not on M2 Macrophages. J. Immunol. 2015, 194, 2330-2337. [CrossRef] [PubMed]

81. Scholz, J.; Woolf, C.J. The Neuropathic Pain Triad: Neurons, Immune Cells and Glia. Nat. Neurosci. 2007, 10, 1361-1368. [CrossRef]

82. Bingham, B.; Ajit, S.K.; Blake, D.R.; Samad, T.A. The Molecular Basis of Pain and Its Clinical Implications in Rheumatology. Nat Clin. Pract. Rheumatol. 2009, 5, 28-37. [CrossRef]

83. Jara-Oseguera, A.; Simon, S.A.; Rosenbaum, T. TRPV1: On the Road to Pain Relief. Curr. Mol. Pharmacol. 2008, 1, 255-269. [CrossRef]

84. Campbell, J.N.; Raja, S.N.; Meyer, R.A.; Mackinnon, S.E. Myelinated Afferents Signal the Hyperalgesia Associated with Nerve Injury. Pain 1988, 32, 89-94. [CrossRef]

85. Schmidtko, A. Nitric Oxide-Mediated Pain Processing in the Spinal Cord. Handb. Exp. Pharmacol. 2015, 227, 103-117. [CrossRef]

86. Lim, J.Y.; Park, C.-K.; Hwang, S.W. Biological Roles of Resolvins and Related Substances in the Resolution of Pain. Biomed. Res. Int. 2015, 2015, 830930. [CrossRef]

87. Serhan, C.N.; Chiang, N.; Dalli, J. New Pro-Resolving n-3 Mediators Bridge Resolution of Infectious Inflammation to Tissue Regeneration. Mol. Asp. Med. 2018, 64, 1-17. [CrossRef] [PubMed]

88. Schwanke, R.C.; Marcon, R.; Bento, A.F.; Calixto, J.B. EPA- and DHA-Derived Resolvins' Actions in Inflammatory Bowel Disease. Eur. J. Pharmacol. 2016, 785, 156-164. [CrossRef]

89. Serhan, C.N.; Dalli, J.; Karamnov, S.; Choi, A.; Park, C.-K.; Xu, Z.-Z.; Ji, R.-R.; Zhu, M.; Petasis, N.A. Macrophage Proresolving Mediator Maresin 1 Stimulates Tissue Regeneration and Controls Pain. FASEB J. 2012, 26, 1755-1765. [CrossRef]

90. Liao, H.-Y.; Hsieh, C.-L.; Huang, C.-P.; Lin, Y.-W. Electroacupuncture Attenuates CFA-Induced Inflammatory Pain by Suppressing Nav1.8 through S100B, TRPV1, Opioid, and Adenosine Pathways in Mice. Sci. Rep. 2017, 7, 42531. [CrossRef] [PubMed]

91. Yu, Y.-Q.; Zhao, F.; Guan, S.-M.; Chen, J. Antisense-Mediated Knockdown of Na(V)1.8, but Not Na(V)1.9, Generates Inhibitory Effects on Complete Freund's Adjuvant-Induced Inflammatory Pain in Rat. PLoS ONE 2011, 6, e19865. [CrossRef]

92. Park, C.-K. Maresin 1 Inhibits TRPV1 in Temporomandibular Joint-Related Trigeminal Nociceptive Neurons and TMJ Inflammation-Induced Synaptic Plasticity in the Trigeminal Nucleus. Mediat. Inflamm. 2015, 2015, 275126. [CrossRef]

93. Park, C.-K.; Lü, N.; Xu, Z.-Z.; Liu, T.; Serhan, C.N.; Ji, R.-R. Resolving TRPV1- and TNF- $\alpha$-Mediated Spinal Cord Synaptic Plasticity and Inflammatory Pain with Neuroprotectin D1. J. Neurosci. 2011, 31, 15072-15085. [CrossRef]

94. Park, C.-K.; Xu, Z.-Z.; Liu, T.; Lü, N.; Serhan, C.N.; Ji, R.-R. Resolvin D2 Is a Potent Endogenous Inhibitor for Transient Receptor Potential Subtype V1/A1, Inflammatory Pain, and Spinal Cord Synaptic Plasticity in Mice: Distinct Roles of Resolvin D1, D2, and E1. J. Neurosci. 2011, 31, 18433-18438. [CrossRef] [PubMed] 
95. Huang, J.; Burston, J.J.; Li, L.; Ashraf, S.; Mapp, P.I.; Bennett, A.J.; Ravipati, S.; Pousinis, P.; Barrett, D.A.; Scammell, B.E.; et al. Targeting the D Series Resolvin Receptor System for the Treatment of Osteoarthritis Pain. Arthritis Rheumatol. 2017, 69, 996-1008. [CrossRef]

96. Bang, S.; Yoo, S.; Yang, T.J.; Cho, H.; Kim, Y.G.; Hwang, S.W. Resolvin D1 Attenuates Activation of Sensory Transient Receptor Potential Channels Leading to Multiple Anti-Nociception. Br. J. Pharmacol. 2010, 161, 707-720. [CrossRef] [PubMed]

97. Macpherson, L.J.; Xiao, B.; Kwan, K.Y.; Petrus, M.J.; Dubin, A.E.; Hwang, S.; Cravatt, B.; Corey, D.P.; Patapoutian, A. An Ion Channel Essential for Sensing Chemical Damage. J. Neurosci. 2007, 27, 11412-11415. [CrossRef]

98. Sommer, C.; Birklein, F. Fighting off Pain with Resolvins. Nat. Med. 2010, 16, 518-520. [CrossRef]

99. Arita, M.; Bianchini, F.; Aliberti, J.; Sher, A.; Chiang, N.; Hong, S.; Yang, R.; Petasis, N.A.; Serhan, C.N. Stereochemical Assignment, Antiinflammatory Properties, and Receptor for the Omega-3 Lipid Mediator Resolvin E1. J. Exp. Med. 2005, 201, 713-722. [CrossRef] [PubMed]

100. Meesawatsom, P.; Burston, J.; Hathway, G.; Bennett, A.; Chapman, V. Inhibitory Effects of Aspirin-Triggered Resolvin D1 on Spinal Nociceptive Processing in Rat Pain Models. J. Neuroinflamm. 2016, 13, 233. [CrossRef]

101. Woolf, C.J.; Salter, M.W. Neuronal Plasticity: Increasing the Gain in Pain. Science 2000, 288, 1765-1768. [CrossRef]

102. Liu, X.J.; Gingrich, J.R.; Vargas-Caballero, M.; Dong, Y.N.; Sengar, A.; Beggs, S.; Wang, S.-H.; Ding, H.K.; Frankland, P.W.; Salter, M.W. Treatment of Inflammatory and Neuropathic Pain by Uncoupling Src from the NMDA Receptor Complex. Nat. Med. 2008, 14, 1325-1332. [CrossRef]

103. Ren, K.; Hylden, J.L.K.; Williams, G.M.; Ruda, M.A.; Dubner, R. The Effects of a Non-Competitive NMDA Receptor Antagonist, MK-801, on Behavioral Hyperalgesia and Dorsal Horn Neuronal Activity in Rats with Unilateral Inflammation. Pain 1992, 50, 331-344. [CrossRef]

104. Quan-Xin, F.; Fan, F.; Xiang-Ying, F.; Shu-Jun, L.; Shi-Qi, W.; Zhao-Xu, L.; Xu-Jie, Z.; Qing-Chuan, Z.; Wei, W. Resolvin D1 Reverses Chronic Pancreatitis-Induced Mechanical Allodynia, Phosphorylation of NMDA Receptors, and Cytokines Expression in the Thoracic Spinal Dorsal Horn. BMC Gastroenterol. 2012, 12, 148. [CrossRef]

105. Oehler, B.; Mohammadi, M.; Perpina Viciano, C.; Hackel, D.; Hoffmann, C.; Brack, A.; Rittner, H.L. Peripheral Interaction of Resolvin D1 and E1 with Opioid Receptor Antagonists for Antinociception in Inflammatory Pain in Rats. Front. Mol. Neurosci. 2017, 10, 242. [CrossRef] [PubMed]

106. Yaksh, T.L. Substance P Release from Knee Joint Afferent Terminals: Modulation by Opioids. Brain Res. 1988, 458, 319-324. [CrossRef]

107. Beaudry, H.; Dubois, D.; Gendron, L. Activation of Spinal Mu- and Delta-Opioid Receptors Potently Inhibits Substance P Release Induced by Peripheral Noxious Stimuli. J. Neurosci. 2011, 31, 13068-13077. [CrossRef] [PubMed]

108. Khasabova, I.A.; Harding-Rose, C.; Simone, D.A.; Seybold, V.S. Differential Effects of CB1 and Opioid Agonists on Two Populations of Adult Rat Dorsal Root Ganglion Neurons. J. Neurosci. 2004, 24, 1744-1753. [CrossRef]

109. Jin, Y.H.; Nishioka, H.; Wakabayashi, K.; Fujita, T.; Yonehara, N. Effect of Morphine on the Release of Excitatory Amino Acids in the Rat Hind Instep: Pain Is Modulated by the Interaction between the Peripheral Opioid and Glutamate Systems. Neuroscience 2006, 138, 1329-1339. [CrossRef]

110. Celik, M.Ö.; Labuz, D.; Henning, K.; Busch-Dienstfertig, M.; Gaveriaux-Ruff, C.; Kieffer, B.L.; Zimmer, A.; Machelska, H. Leukocyte Opioid Receptors Mediate Analgesia via Ca(2+)-Regulated Release of Opioid Peptides. Brain Behav. Immun. 2016, 57, $227-242$. [CrossRef]

111. Chuang, T.K.; Killam, K.F.; Chuang, L.F.; Kung, H.F.; Sheng, W.S.; Chao, C.C.; Yu, L.; Chuang, R.Y. Mu Opioid Receptor Gene Expression in Immune Cells. Biochem. Biophys. Res. Commun. 1995, 216, 922-930. [CrossRef] [PubMed]

112. Toskulkao, T.; Pornchai, R.; Akkarapatumwong, V.; Vatanatunyakum, S.; Govitrapong, P. Alteration of Lymphocyte Opioid Receptors in Methadone Maintenance Subjects. Neurochem. Int. 2010, 56, 285-290. [CrossRef]

113. Machelska, H.; Celik, M.Ö. Opioid Receptors in Immune and Glial Cells-Implications for Pain Control. Front. Immunol. 2020, 11, 300. [CrossRef] [PubMed]

114. Luo, X.; Gu, Y.; Tao, X.; Serhan, C.N.; Ji, R.-R. Resolvin D5 Inhibits Neuropathic and Inflammatory Pain in Male but Not Female Mice: Distinct Actions of D-Series Resolvins in Chemotherapy-Induced Peripheral Neuropathy. Front. Pharmacol. 2019, 10, 745. [CrossRef]

115. Krishnamoorthy, S.; Recchiuti, A.; Chiang, N.; Yacoubian, S.; Lee, C.-H.; Yang, R.; Petasis, N.A.; Serhan, C.N. Resolvin D1 Binds Human Phagocytes with Evidence for Proresolving Receptors. Proc. Natl. Acad. Sci. USA 2010, 107, 1660-1665. [CrossRef] [PubMed]

116. Serhan, C.N.; Hong, S.; Gronert, K.; Colgan, S.P.; Devchand, P.R.; Mirick, G.; Moussignac, R.-L. Resolvins: A Family of Bioactive Products of Omega-3 Fatty Acid Transformation Circuits Initiated by Aspirin Treatment That Counter Proinflammation Signals. J. Exp. Med. 2002, 196, 1025-1037. [CrossRef] [PubMed]

117. Qu, L.; Caterina, M.J. Accelerating the Reversal of Inflammatory Pain with NPD1 and Its Receptor GPR37. J. Clin. Investig. 2018, 128, 3246-3249. [CrossRef]

118. Chen, O.; Donnelly, C.R.; Ji, R.-R. Regulation of Pain by Neuro-Immune Interactions between Macrophages and Nociceptor Sensory Neurons. Curr. Opin. Neurobiol. 2020, 62, 17-25. [CrossRef] [PubMed]

119. Pannell, M.; Labuz, D.; Celik, M.Ö.; Keye, J.; Batra, A.; Siegmund, B.; Machelska, H. Adoptive Transfer of M2 Macrophages Reduces Neuropathic Pain via Opioid Peptides. J. Neuroinflamm. 2016, 13, 262. [CrossRef] 
120. Wang, J.C.-F.; Strichartz, G.R. Prevention of Chronic Post-Thoracotomy Pain in Rats by Intrathecal Resolvin D1 and D2: Effectiveness of Perioperative and Delayed Drug Delivery. J. Pain 2017, 18, 535-545. [CrossRef] [PubMed]

121. Pamplona, F.A.; Ferreira, J.; de Lima, O.M.; Duarte, F.S.; Bento, A.F.; Forner, S.; Villarinho, J.G.; Bellocchio, L.; Wotjak, C.T.; Lerner, R.; et al. Anti-Inflammatory Lipoxin A4 Is an Endogenous Allosteric Enhancer of CB1 Cannabinoid Receptor. Proc. Natl. Acad. Sci. USA 2012, 109, 21134-21139. [CrossRef] [PubMed]

122. Zhang, H.; He, S.; Hu, Y.; Zheng, H. Antagonism of Cannabinoid Receptor 1 Attenuates the Anti-Inflammatory Effects of Electroacupuncture in a Rodent Model of Migraine. Acupunct. Med. 2016, 34, 463-470. [CrossRef]

123. Xu, Z.-Z.; Berta, T.; Ji, R.-R. Resolvin E1 Inhibits Neuropathic Pain and Spinal Cord Microglial Activation Following Peripheral Nerve Injury. J. Neuroimmune Pharmacol. 2013, 8, 37-41. [CrossRef] [PubMed]

124. Hernangómez, M.; Klusáková, I.; Joukal, M.; Hradilová-Svíženská, I.; Guaza, C.; Dubový, P. CD200R1 Agonist Attenuates Glial Activation, Inflammatory Reactions, and Hypersensitivity Immediately after Its Intrathecal Application in a Rat Neuropathic Pain Model. J. Neuroinflamm. 2016, 13, 43. [CrossRef] [PubMed]

125. Gao, Y.-J.; Ji, R.-R. Activation of JNK Pathway in Persistent Pain. Neurosci. Lett. 2008, 437, 180-183. [CrossRef]

126. Tsuda, M.; Inoue, K.; Salter, M.W. Neuropathic Pain and Spinal Microglia: A Big Problem from Molecules in "Small" Glia. Trends Neurosci. 2005, 28, 101-107. [CrossRef]

127. Svensson, C.I.; Zattoni, M.; Serhan, C.N. Lipoxins and Aspirin-Triggered Lipoxin Inhibit Inflammatory Pain Processing. J. Exp. Med. 2007, 204, 245-252. [CrossRef]

128. Miao, G.-S.; Liu, Z.-H.; Wei, S.-X.; Luo, J.-G.; Fu, Z.-J.; Sun, T. Lipoxin A4 Attenuates Radicular Pain Possibly by Inhibiting Spinal ERK, JNK and NF-KB/P65 and Cytokine Signals, but Not P38, in a Rat Model of Non-Compressive Lumbar Disc Herniation. Neuroscience 2015, 300, 10-18. [CrossRef]

129. Liu, J.; Peng, L.; Li, J. The Lipoxin A4 Receptor Agonist BML-111 Alleviates Inflammatory Injury and Oxidative Stress in Spinal Cord Injury. Med. Sci. Monit. 2020, 26, e919883. [CrossRef] [PubMed]

130. Ji, R.-R.; Suter, M.R. P38 MAPK, Microglial Signaling, and Neuropathic Pain. Mol. Pain 2007, 3, 33. [CrossRef] [PubMed]

131. Diamond, P.; Doran, P.; Brady, H.R.; McGinty, A. Suppressors of Cytokine Signalling (SOCS): Putative Modulators of Cytokine Bioactivity in Health and Disease. J. Nephrol. 2000, 13, 9-14.

132. Hu, S.; Mao-Ying, Q.-L.; Wang, J.; Wang, Z.-F.; Mi, W.-L.; Wang, X.-W.; Jiang, J.-W.; Huang, Y.-L.; Wu, G.-C.; Wang, Y.-Q. Lipoxins and Aspirin-Triggered Lipoxin Alleviate Bone Cancer Pain in Association with Suppressing Expression of Spinal Proinflammatory Cytokines. J. Neuroinflamm. 2012, 9, 278. [CrossRef]

133. Zhang, L.-Y.; Liu, Z.-H.; Zhu, Q.; Wen, S.; Yang, C.-X.; Fu, Z.-J.; Sun, T. Resolvin D2 Relieving Radicular Pain Is Associated with Regulation of Inflammatory Mediators, Akt/GSK-3ß Signal Pathway and GPR18. Neurochem. Res. 2018, 43, 2384-2392. [CrossRef] [PubMed]

134. Xu, Z.-Z.; Liu, X.-J.; Berta, T.; Park, C.-K.; Lü, N.; Serhan, C.N.; Ji, R.-R. Neuroprotectin/Protectin D1 Protects against Neuropathic Pain in Mice after Nerve Trauma. Ann. Neurol. 2013, 74, 490-495. [CrossRef]

135. Gao, J.; Tang, C.; Tai, L.W.; Ouyang, Y.; Li, N.; Hu, Z.; Chen, X. Pro-Resolving Mediator Maresin 1 Ameliorates Pain Hypersensitivity in a Rat Spinal Nerve Ligation Model of Neuropathic Pain. J. Pain Res. 2018, 11, 1511-1519. [CrossRef]

136. Fukumoto, M.; Takeuchi, T.; Koubayashi, E.; Harada, S.; Ota, K.; Kojima, Y.; Higuchi, K. Induction of Brain-Derived Neurotrophic Factor in Enteric Glial Cells Stimulated by Interleukin-1 $\beta$ via a c-Jun N-Terminal Kinase Pathway. J. Clin. Biochem. Nutr. 2020, 66, 103-109. [CrossRef]

137. Yu, Y.-B.; Zuo, X.-L.; Zhao, Q.-J.; Chen, F.-X.; Yang, J.; Dong, Y.-Y.; Wang, P.; Li, Y.-Q. Brain-Derived Neurotrophic Factor Contributes to Abdominal Pain in Irritable Bowel Syndrome. Gut 2012, 61, 685-694. [CrossRef]

138. Reischer, G.; Heinke, B.; Sandkühler, J. Interferon- $\gamma$ Facilitates the Synaptic Transmission between Primary Afferent C-Fibres and Lamina I Neurons in the Rat Spinal Dorsal Horn via Microglia Activation. Mol. Pain 2020, 16, 1744806920917249. [CrossRef] [PubMed]

139. Coull, J.A.M.; Beggs, S.; Boudreau, D.; Boivin, D.; Tsuda, M.; Inoue, K.; Gravel, C.; Salter, M.W.; De Koninck, Y. BDNF from Microglia Causes the Shift in Neuronal Anion Gradient Underlying Neuropathic Pain. Nature 2005, 438, 1017-1021. [CrossRef] [PubMed]

140. Kim, D.; Kim, M.A.; Cho, I.-H.; Kim, M.S.; Lee, S.; Jo, E.-K.; Choi, S.-Y.; Park, K.; Kim, J.S.; Akira, S.; et al. A Critical Role of Toll-like Receptor 2 in Nerve Injury-Induced Spinal Cord Glial Cell Activation and Pain Hypersensitivity. J. Biol. Chem. 2007, 282, 14975-14983. [CrossRef]

141. Zhuang, Z.-Y.; Kawasaki, Y.; Tan, P.-H.; Wen, Y.-R.; Huang, J.; Ji, R.-R. Role of the CX3CR1/P38 MAPK Pathway in Spinal Microglia for the Development of Neuropathic Pain Following Nerve Injury-Induced Cleavage of Fractalkine. Brain Behav. Immun. 2007, 21, 642-651. [CrossRef]

142. Wu, L.; Liu, Z.J.; Miao, S.; Zou, L.B.; Cai, L.; Wu, P.; Ye, D.Y.; Wu, Q.; Li, H.H. Lipoxin A4 Ameliorates Cerebral Ischaemia/Reperfusion Injury through Upregulation of Nuclear Factor Erythroid 2-Related Factor 2. Neurol. Res. 2013, 35, 968-975. [CrossRef]

143. Wu, Y.; Zhai, H.; Wang, Y.; Li, L.; Wu, J.; Wang, F.; Sun, S.; Yao, S.; Shang, Y. Aspirin-Triggered Lipoxin $\mathrm{A}_{4}$ Attenuates Lipopolysaccharide-Induced Intracellular ROS in BV2 Microglia Cells by Inhibiting the Function of NADPH Oxidase. Neurochem. Res. 2012, 37, 1690-1696. [CrossRef] [PubMed]

144. Arita, M.; Ohira, T.; Sun, Y.-P.; Elangovan, S.; Chiang, N.; Serhan, C.N. Resolvin E1 Selectively Interacts with Leukotriene B4 Receptor BLT1 and ChemR23 to Regulate Inflammation. J. Immunol. 2007, 178, 3912-3917. [CrossRef] 
145. Liu, Z.-Q.; Zhang, H.-B.; Wang, J.; Xia, L.-J.; Zhang, W. Lipoxin A4 Ameliorates Ischemia/Reperfusion Induced Spinal Cord Injury in Rabbit Model. Int. J. Clin. Exp. Med. 2015, 8, 12826-12833.

146. Leuti, A.; Maccarrone, M.; Chiurchiù, V. Proresolving Lipid Mediators: Endogenous Modulators of Oxidative Stress. Oxid. Med. Cell. Longev. 2019, 2019, 8107265. [CrossRef]

147. Tsujino, H.; Kondo, E.; Fukuoka, T.; Dai, Y.; Tokunaga, A.; Miki, K.; Yonenobu, K.; Ochi, T.; Noguchi, K. Activating Transcription Factor 3 (ATF3) Induction by Axotomy in Sensory and Motoneurons: A Novel Neuronal Marker of Nerve Injury. Mol. Cell. Neurosci. 2000, 15, 170-182. [CrossRef]

148. Ohuchi, K.; Ono, Y.; Joho, M.; Tsuruma, K.; Ogami, S.; Yamane, S.; Funato, M.; Kaneko, H.; Nakamura, S.; Hara, H.; et al. A Docosahexaenoic Acid-Derived Pro-Resolving Agent, Maresin 1, Protects Motor Neuron Cells Death. Neurochem. Res. 2018, 43, 1413-1423. [CrossRef] [PubMed]

149. Serhan, C.N.; Chiang, N.; Dalli, J. The Resolution Code of Acute Inflammation: Novel pro-Resolving Lipid Mediators in Resolution. Semin. Immunol. 2015, 27, 200-215. [CrossRef] [PubMed]

150. Paragomi, P.; Rahimian, R.; Kazemi, M.H.; Gharedaghi, M.H.; Khalifeh-Soltani, A.; Azary, S.; Javidan, A.N.; Moradi, K.; Sakuma, S.; Dehpour, A.R. Antinociceptive and Antidiarrheal Effects of Pioglitazone in a Rat Model of Diarrhoea-Predominant Irritable Bowel Syndrome: Role of Nitric Oxide. Clin. Exp. Pharmacol. Physiol. 2014, 41, 118-126. [CrossRef] [PubMed]

151. Piovezan, A.P.; Batisti, A.P.; Benevides, M.L.A.C.S.; Turnes, B.L.; Martins, D.F.; Kanis, L.; Duarte, E.C.W.; Cavalheiro, A.J.; Bueno, P.C.P.; Seed, M.P.; et al. Hydroalcoholic Crude Extract of Casearia Sylvestris Sw. Reduces Chronic Post-Ischemic Pain by Activation of pro-Resolving Pathways. J. Ethnopharmacol. 2017, 204, 179-188. [CrossRef] [PubMed]

152. Abdelmoaty, S.; Wigerblad, G.; Bas, D.B.; Codeluppi, S.; Fernandez-Zafra, T.; El-Awady, E.-S.; Moustafa, Y.; Abdelhamid, A.E.S.; Brodin, E.; Svensson, C.I. Spinal Actions of Lipoxin A4 and 17(R)-Resolvin D1 Attenuate Inflammation-Induced Mechanical Hypersensitivity and Spinal TNF Release. PLOS ONE 2013, 8, e75543. [CrossRef]

153. Lu, T.; Wu, X.; Wei, N.; Liu, X.; Zhou, Y.; Shang, C.; Duan, Y.; Dong, Y. Lipoxin A4 Protects against Spinal Cord Injury via Regulating Akt/Nuclear Factor (Erythroid-Derived 2)-like 2/Heme Oxygenase-1 Signaling. Biomed. Pharmacother. 2018, 97, 905-910. [CrossRef] [PubMed]

154. Wang, Z.F.; Li, Q.; Liu, S.B.; Mi, W.-L.; Hu, S.; Zhao, J.; Tian, Y.; Mao-Ying, Q.L.; Jiang, J.W.; Ma, H.J.; et al. Aspirin-Triggered Lipoxin A4 Attenuates Mechanical Allodynia in Association with Inhibiting Spinal JAK2/STAT3 Signaling in Neuropathic Pain in Rats. Neuroscience 2014, 273, 65-78. [CrossRef]

155. Sun, T.; Yu, E.; Yu, L.; Luo, J.; Li, H.; Fu, Z. LipoxinA(4) Induced Antinociception and Decreased Expression of NF-KB and pro-Inflammatory Cytokines after Chronic Dorsal Root Ganglia Compression in Rats. Eur. J. Pain 2012, 16, 18-27. [CrossRef]

156. Tian, Y.; Liu, M.; Mao-Ying, Q.-L.; Liu, H.; Wang, Z.-F.; Zhang, M.-T.; Wang, J.; Li, Q.; Liu, S.-B.; Mi, W.-L.; et al. Early Single Aspirin-Triggered Lipoxin Blocked Morphine Anti-Nociception Tolerance through Inhibiting NALP1 Inflammasome: Involvement of PI3k/Akt Signaling Pathway. Brain Behav. Immun. 2015, 50, 63-77. [CrossRef]

157. Huang, L.; Wang, C.-F.; Serhan, C.N.; Strichartz, G. Enduring Prevention and Transient Reduction of Postoperative Pain by Intrathecal Resolvin D1. Pain 2011, 152, 557-565. [CrossRef] [PubMed]

158. Liu, Z.; Miao, G.; Wang, J.; Yang, C.; Fu, Z.; Sun, T. Resolvin D1 Inhibits Mechanical Hypersensitivity in Sciatica by Modulating the Expression of Nuclear Factor-KB, Phospho-Extracellular Signal-Regulated Kinase, and Pro- and Antiinflammatory Cytokines in the Spinal Cord and Dorsal Root Ganglion. Anesthesiology 2016, 124, 934-944. [CrossRef]

159. Zhang, L.; Terrando, N.; Xu, Z.-Z.; Bang, S.; Jordt, S.-E.; Maixner, W.; Serhan, C.N.; Ji, R.-R. Distinct Analgesic Actions of DHA and DHA-Derived Specialized Pro-Resolving Mediators on Post-Operative Pain after Bone Fracture in Mice. Front. Pharmacol. 2018, 9, 412. [CrossRef]

160. Klein, C.P.; Sperotto, N.D.M.; Maciel, I.S.; Leite, C.E.; Souza, A.H.; Campos, M.M. Effects of D-Series Resolvins on Behavioral and Neurochemical Changes in a Fibromyalgia-like Model in Mice. Neuropharmacology 2014, 86, 57-66. [CrossRef] [PubMed]

161. Fonseca, F.C.; Orlando, R.M.; Turchetti-Maia, R.M.; de Francischi, J.N. Comparative Effects of the $\Omega 3$ Polyunsaturated Fatty Acid Derivatives Resolvins E1 and D1 and Protectin DX in Models of Inflammation and Pain. J. Inflamm. Res. 2017, 10, 119-133. [CrossRef]

162. Barden, A.; Mas, E.; Croft, K.D.; Phillips, M.; Mori, T.A. Short-Term n-3 Fatty Acid Supplementation but Not Aspirin Increases Plasma Proresolving Mediators of Inflammation. J. Lipid Res. 2014, 55, 2401-2407. [CrossRef]

163. Tjonahen, E.; Oh, S.F.; Siegelman, J.; Elangovan, S.; Percarpio, K.B.; Hong, S.; Arita, M.; Serhan, C.N. Resolvin E2: Identification and Anti-Inflammatory Actions: Pivotal Role of Human 5-Lipoxygenase in Resolvin E Series Biosynthesis. Chem. Biol. 2006, 13, 1193-1202. [CrossRef] [PubMed]

164. Isobe, Y.; Arita, M.; Iwamoto, R.; Urabe, D.; Todoroki, H.; Masuda, K.; Inoue, M.; Arai, H. Stereochemical Assignment and Anti-Inflammatory Properties of the Omega-3 Lipid Mediator Resolvin E3. J. Biochem. 2013, 153, 355-360. [CrossRef] [PubMed]

165. A.T. Resolve SARL. A Multicenter, Double-Masked, Parallel-Group, Vehicle-Controlled Study to Assess the Efficacy and Safety of RX-10045 Nanomicellar Ophthalmic Solution for Treatment of Ocular Inflammation and Pain in Subjects Undergoing Cataract Surgery. 2019. Available online: clinicaltrials.gov (accessed on 10 July 2021).

166. Ramsden, C.E.; Faurot, K.R.; Zamora, D.; Palsson, O.S.; MacIntosh, B.A.; Gaylord, S.; Taha, A.Y.; Rapoport, S.I.; Hibbeln, J.R.; Davis, J.M.; et al. Targeted Alterations in Dietary N-3 and n-6 Fatty Acids Improve Life Functioning and Reduce Psychological Distress among Patients with Chronic Headache: A Secondary Analysis of a Randomized Trial. Pain 2015, 156, 587-596. [CrossRef] 
167. Tajmirriahi, M.; Sohelipour, M.; Basiri, K.; Shaygannejad, V.; Ghorbani, A.; Saadatnia, M. The Effects of Sodium Valproate with Fish Oil Supplementation or Alone in Migraine Prevention: A Randomized Single-Blind Clinical Trial. Iran. J. Neurol. 2012, 11, 21-24.

168. Caturla, N.; Funes, L.; Pérez-Fons, L.; Micol, V. A Randomized, Double-Blinded, Placebo-Controlled Study of the Effect of a Combination of Lemon Verbena Extract and Fish Oil Omega-3 Fatty Acid on Joint Management. J. Altern. Complement. Med. 2011, 17, 1051-1063. [CrossRef]

169. Tomer, A.; Kasey, S.; Connor, W.E.; Clark, S.; Harker, L.A.; Eckman, J.R. Reduction of Pain Episodes and Prothrombotic Activity in Sickle Cell Disease by Dietary N-3 Fatty Acids. Thromb. Haemost. 2001, 85, 966-974. [CrossRef]

170. Durán, A.M.; Salto, L.M.; Câmara, J.; Basu, A.; Paquien, I.; Beeson, W.L.; Firek, A.; Cordero-MacIntyre, Z.; De León, M. Effects of Omega-3 Polyunsaturated Fatty-Acid Supplementation on Neuropathic Pain Symptoms and Sphingosine Levels in Mexican-Americans with Type 2 Diabetes. Diabetes Metab. Syndr. Obes. Targets Ther. 2019, 12, 109-120. [CrossRef]

171. Barden, A.E.; Moghaddami, M.; Mas, E.; Phillips, M.; Cleland, L.G.; Mori, T.A. Specialised Pro-Resolving Mediators of Inflammation in Inflammatory Arthritis. Prostaglandins Leukot. Essent. Fatty Acids 2016, 107, 24-29. [CrossRef]

172. Kremer, J.M.; Lawrence, D.A.; Jubiz, W.; DiGiacomo, R.; Rynes, R.; Bartholomew, L.E.; Sherman, M. Dietary Fish Oil and Olive Oil Supplementation in Patients with Rheumatoid Arthritis. Clinical and Immunologic Effects. Arthritis Rheum. Off. J. Am. Coll. Rheumatol. 1990, 33, 810-820. [CrossRef] [PubMed]

173. Geusens, P.; Wouters, C.; Nijs, J.; Jiang, Y.; Dequeker, J. Long-Term Effect of Omega-3 Fatty Acid Supplementation in Active Rheumatoid Arthritis. A 12-Month, Double-Blind, Controlled Study. Arthritis Rheum. Off. J. Am. Coll. Rheumatol. 1994, 37, 824-829. [CrossRef] [PubMed]

174. Tulleken, J.E.; Limburg, P.C.; Muskiet, F.A.; van Rijswijk, M.H. Vitamin E Status during Dietary Fish Oil Supplementation in Rheumatoid Arthritis. Arthritis Rheum. Off. J. Am. Coll. Rheumatol. 1990, 33, 1416-1419. [CrossRef] [PubMed]

175. Galarraga, B.; Khan, F.; Kumar, P.; Pullar, T.; Belch, J.J.F. C-Reactive Protein: The Underlying Cause of Microvascular Dysfunction in Rheumatoid Arthritis. Rheumatology 2008, 47, 1780-1784. [CrossRef] [PubMed]

176. Lamon-Fava, S.; So, J.; Mischoulon, D.; Ziegler, T.R.; Dunlop, B.W.; Kinkead, B.; Schettler, P.J.; Nierenberg, A.A.; Felger, J.C.; Maddipati, K.R.; et al. Dose- and Time-Dependent Increase in Circulating Anti-Inflammatory and pro-Resolving Lipid Mediators Following Eicosapentaenoic Acid Supplementation in Patients with Major Depressive Disorder and Chronic Inflammation. Prostaglandins Leukot. Essent. Fatty Acids 2021, 164, 102219. [CrossRef] [PubMed]

177. Abdelhalim, S.M.N.S. Comparative Effectiveness of the Different Treatment Modalities for Management of Vaso-Occlusive Painful Crisis in Pediatric Sickle Cell Disease. 2021. Available online: clinicaltrials.gov (accessed on 10 July 2021).

178. Kenney, K. Targeted Alteration in Omega-3 and Omega-6 Fatty Acids for Post-Traumatic Headache (Nutrition for PTH). 2018. Available online: clinicaltrials.gov (accessed on 10 July 2021).

179. Universidade do Porto. Effects of an Anti-Inflammatory Nutritional Intervention in Disease Assessment Parameters, Inflammatory Markers, and Quality of Life of Patients with Fibromyalgia. 2020. Available online: clinicaltrials.gov (accessed on 10 July 2021).

180. Costenbader, K.H. Vitamin D and Fish Oil for Autoimmune Disease, Inflammation and Knee Pain. 2021. Available online: clinicaltrials.gov (accessed on 10 July 2021).

181. University of North Carolina. Chapel Hill Pilot, Double-Blind, Randomized Controlled, Multi-Center Study of the Effects of Fish Oil and Vitamin D in the Prevention of Chronic Pain Following Major Thermal Burn Injury. 2020. Available online: clinicaltrials.gov (accessed on 10 July 2021).

182. Swisse Wellness Pty Ltd. A Randomised, Double-Blind, Placebo Controlled Study to Investigate the Effect on Knee Pain Reduction and Safety of Swisse High Strength Deep Sea Krill Oil (Superba BOOST) in Adults with Mild to Moderate Osteoarthritis of the Knee. 2020. Available online: clinicaltrials.gov (accessed on 10 July 2021). 